\title{
PROBLEMATIKA KOSMOGONIE V PLATÓNOVĚ DIALOGU TIMAIOS
}

\section{Jiří Stránský}

\section{Úvod}

Dialog Timaios patří mezi nejznámější a nejvíce komentovaná Platónova díla. Tato skutečnost nepochybně úzce souvisí s bohatstvím témat, která jsou v něm zahrnuta a jež spadají zejména do theologie, kosmologie, astronomie, antropologie, psychologie či př́rodní filosofie. ${ }^{1}$ Dialog je pojmenován podle svého hlavního řečníka, ten - vzhledem $\mathrm{k}$ tomu, že má být ze všech prrítomných nejlepším astronomem a že se nejvíce věnuje nauce o prŕrodě ( podat výklad, jenž by začínal vznikem kosmu a končil zrozením lidí. Timaios tomuto zadání vyhoví a pronáší svoji ,,velkou řeč“, jež tvoří celý zbytek dialogu. V rámci této studie se soustředíme na několik vybraných otázek, které považujeme za klíčové a bez jejichž zodpovězení nelze dialogu adekvátně porozumět. Jako první detailně rozebereme prooimion k Timaiově ,,velké řeči“, v němž se objevují témata zásadním způsobem určující výklad zbytku dialogu: jde zejména o problematiku vzniku, či věčné existence kosmu a problematiku povahy řeči, kterou lze o kosmu pronášet. Naši interpretaci pak dále rozpracujeme na základě rozboru konkrétních rysů timaiovské kosmogonie a pokusíme se ji konfrontovat s vybranými alternativními výklady renomovaných badatelů.

\section{Prooimion (Tim. 27c1-29d3)}

Platónův hlavní řečník Timaios dostává slovo, aby promluvil „počínaje od vzniku světa až po zrození člověka“" (Tim. 27a5-6). ${ }^{2}$ Před samotnou

1 Srv. D. Sedley, Hesiod's Theogony and Plato's Timaeus, in: G. R. Boys-Stones - J. H. Haubold (vyd.), Plato and Hesiod, Oxford 2009, str. 246, a týž, Creationism and its Critics in Antiquity, Berkeley - Los Angeles - London 2007, str. 96.

2 Při citacích primárního textu vycházíme z českého překladu Františka Novotného. 
řečí na toto téma, která tvoří celý zbytek dialogu, však Timaios považuje za nezbytné přednést prooimion, $v$ němž představí několik fundamentálních východisek, bez nichž by jeho následující výklad mohl být obtížně srozumitelný, resp. bez nichž by přinejmenším nebyl patřičně zasazen do širších souvislostí. Tato pasáž tedy poskytuje nepostradatelné hermeneutické vodítko k pochopení Timaiovy „,velké řeči“, a z tohoto důvodu se ji nyní pokusíme podrobně vyložit.

\section{Kosmos vzniklý, či stále vznikající?}

Pro odpověd' na tuto otázku se obrat'me nejprve k první části prooimia, tzn. k pasáži Tim. 27c1-28c2. Do značné míry je to právě tento text, jehož výklad rozděluje čtenáře Platónova Timaia do dvou „táborů“: zatímco jedni na jeho základě soudí, že Platónův kosmos vznikl, tzn., že mu předcházel ${ }^{3}$ takový stav veškerenstva, jenž kosmem nebyl, druzí se právě naopak domnívají, že kosmos ve skutečnosti singulárně vzniklý není ${ }^{4}$ a že Platón jej svým výkladem pouze zařazuje do určité ontologické kategorie, totiž mezi jsoucna vznikající a nikdy skutečně jsoucí. ${ }^{5}$ První zmíněnou interpretaci nazývejme ,reálnou“, druhou pak „metaforickou“.

3 V otázce, zda lze toto předcházení chápat v temporálním smyslu, či nikoli, nepanuje mezi zastánci tohoto čtení shoda. Této otázce se budeme podrobněji věnovat v průběhu následujícího výkladu.

4 Termín „singularita“ (resp. adjektivum „singulární“ či označení „singulárně vzniklý“") používáme pro popis bodu, v němž dochází k radikální transformaci veškerenstva, a to ze stavu prekosmického ve stav kosmický. Tento bod vnáší do „,vývoje“ veškerenstva diskontinuitu, přestávají v něm platit charakteristiky a zákonitosti prekosmického stavu (pokud vůbec lze o něčem takovém smysluplně hovořit) a ustavují se charakteristiky a zákonitosti stavu kosmického.

5 Tento spor vznikl už v debatě mezi Platónovými př́mými žáky (Aristotelem na straně jedné a Speusippem, resp. Xenokratem, na straně druhé), pokračoval u středních platoniků i novoplatoniků a není o nic méně živý ani mezi současnými badateli. Není cílem ani v možnostech této studie důkladně zmapovat debatu,jež se po stovky let odehrávala nad textem Platónova Timaia, a představit detailně pozice jednotlivých myslitelů, pročež se až na výjimky omezíme na sekundární literaturu z 20. století. Čtenáře zajímající se o problematiku antických komentářủ lze odkázat např. na následující místa v literatuře: A. E. Taylor, A Commentary on Plato's Timaeus, Oxford 1928, str. 67-69, L. Tarán, Creation Myth in Plato's Timaeus, in: týž, Leonardo Tarán: Collected Papers (1962-1999), Leiden - Boston - Köln 2001, str. 332-336 nebo R. Sorabji, Time, Creation \& the Continuum, London 1983, str. 268-275. Ve všech třech případech se jedná spíše o stručné přehledy, nesrovnatelně podrobněji se dané problematice věnuje Matthias Baltes ve své dvousvazkové monografii 
Na počátku prooimia $\mathrm{v}$ pasáži Tim. 27c1-d4 jsou nám poskytnuty tři důležité informace: 1) Timaios jako hlavní téma svého budoucího výkladu explicitně určuje veškerenstvo ( ò $\pi \hat{o} v$ ), konkrétněji pak otázku,

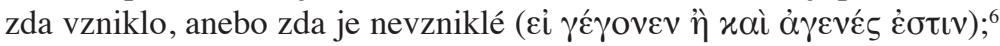
2) Timaios vzývá bohy a bohyně, aby vše pověděl ve shodě s jejich

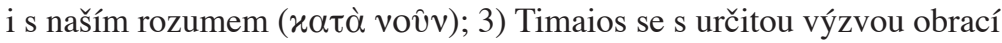
také sám na sebe a na své posluchače - přeje si, aby co nejlépe vyložil,

Die Weltentstehung des Platonischen Timaios nach den antiken Interpreten, I, II, Leiden 1976 a 1978. Nutno však dodat, že Baltesova práce končí výkladem Proklova komentáře, a nezahrnuje tak např. důležitou kritiku Prokla od alexandrijského filosofa Jana Filopona v jeho díle De aeternitate mundi contra Proclum.

6 Na základě argumentů, které podal John Whittaker (viz zejm. J. Whittaker, Timaeus $27 d$ ff., in: Phoenix, 23, 1969, str. 184-185, pozn. 15, a týž, Textual Comments on Timaeus $27 c-d$, in: Phoenix, 27, 1973, str. 388-391), volíme jiné znění této pasáže než Burnet, jenž čte: kritizuje Burnetovo čtení klíčového rukopisu (Parisinus graecus 1807 (A), v němž není Burnetem uvedený tvar ị - ióta není subskribována a její status je zpochybněn tečkou, viz J. Whittaker, Textual Comments on Timaeus 27 c-d, str. 389-390), jednak se dovolává svědectví vybraných antických interpretů Platónova textu (týž, Textual Comments on Timaeus 27 c-d, str. 388-389, a týž, Timaeus $27 d$ fff., str. 184-185, pozn. 15). Za podrobnější zmínku stojí zejména jedna pasáž z Proklova komentáře k našemu dialogu (In Tim. 1.218.28-1.219.31), kde se na základě odlišného kladení ostrých a jemných přídechů nad $\eta$ rozlišují tř̌i možné způsoby čtení. $O$ veškerenstvu

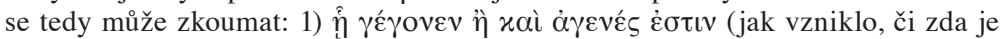

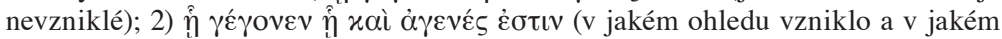

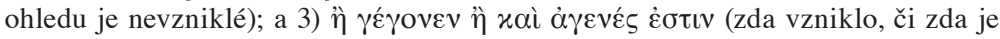
nevzniklé). Proklos sám se kloní ke třetí možnosti, přičemž proti zastáncům prvních dvou variant namítá, že Platón o veškerenstvu nikdy netvrdí, že by bylo v jistém ohledu vzniklé a v jiném ohledu nevzniklé. Whittaker dále dodává, že ona éta v Proklově textu nemusí nutně odkazovat k písmenu řecké abecedy, ale může být spíše fonetickým ekvivalentem, a tudíž s jemným přídechem může kromě ì zastupovat také ei (J. Whittaker, Textual Comments on Timaeus $27 c-d$, str. 390). Výše uvedené varianty 1) a 3) bychom tedy mohli reformulovat také v podobě 1a)

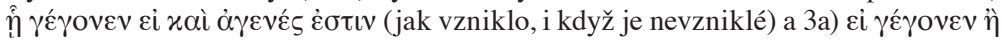

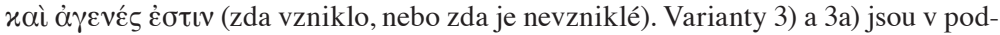
statě synonymní, avšak možnost 3a) považujeme za stylisticky vhodnější. Podobně snad uvažoval i sám Proklos, nebot' v přímé citaci Platónova textu volí možnost 3) (In Tim. 1.217.4-6), avšak ve volnější parafrázi používá 3a) (In Tim. 1.275.10, srv. taktéž Filoponos, De aet. mund. 186.20-21). Dále se domníváme, že varianta 3), resp. 3a), má i jiné výhody. Jako jediná totiž zřetelně formuluje otázku, zda je veškerenstvo vzniklé, či nikoli (která by logicky měla být prioritní vůči otázce, jak veškerenstvo vzniklo), a odpověd’ na ni ponechává zatím zcela otevřenou. Naproti tomu možnost 1) zvláštním způsobem směšuje otázku jak s otázkou zda a obrací jejich logické pořadí. Možnosti 1a) a 2) pak otázku zda explicitně vůbec neformulují a implicitně počítají s negativní odpovědí. 
jak smýšlí o daném tématu (ị $\delta \iota \alpha v o o v ̂ \mu \alpha \iota)$, a aby jej posluchači co

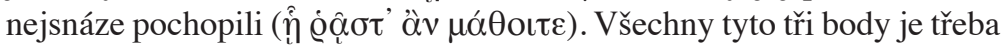
mít na paměti při interpretaci následujícího textu.

Pro správné objasnění otázky po vzniku a povaze kosmu je nejprve provedena základní ontologicko-epistemologická distinkce mezi tím, co

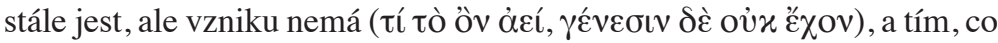

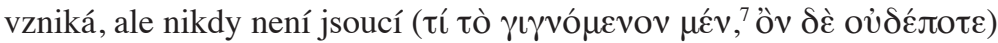
(Tim.27d5-28a1). Timaios na tomto místě pravděpodobně předpokládá

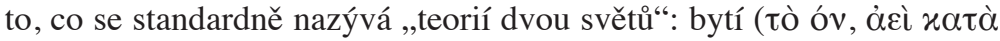

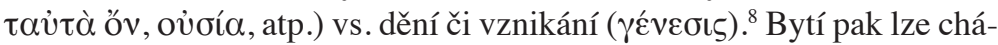

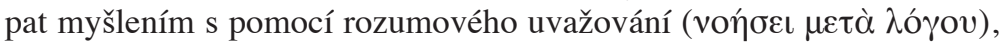
zatímco vznikání lze chápat míněním s pomocí nerozumového smys-

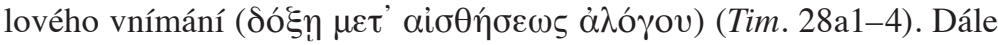
Timaios stanovuje základní aitiologické pravidlo: vše, co náleží do sféry

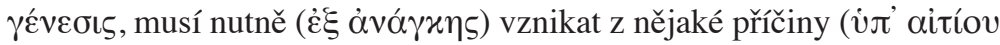

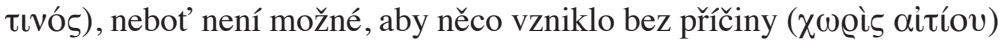
(Tim. 28a4-6). Jako poslední na takto obecné rovině následuje základní mimetické pravidlo: ${ }^{9}$ pokud tvůrce (

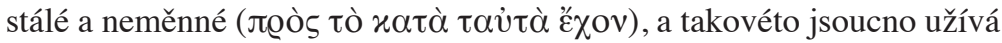

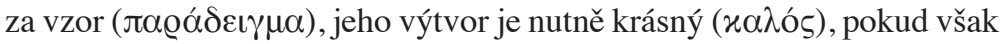

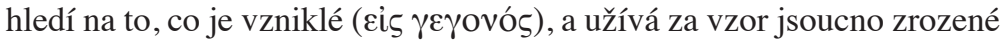

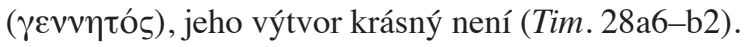

Timaios na tomto místě tedy formuluje základní principy ontologie, epistemologie, aitiologie a mimése, které jsou nezbytné pro adekvátní

7 Také zde dáváme přednost Whittakerovu čtení před Burnetovým, a vynecháváme tudíž slovo ớcí. Whittaker i v tomto případě kritizuje Burnetovu práci s relevantními rukopisy (v rukopisu Vaticanus Palatinus graecus $173(P)$ ỏeí chybí zcela, a Burnet se na něj tedy odvolává chybně, v rukopisu Parisinus graecus 1807 (A) se d’eí sice vyskytuje, ale jeho status je zpochybněn tečkami nad počáteční alfou a koncovou iótou) (J. Whittaker, Textual Comments on Timaeus 27 c-d, str. 387-388) a znovu se dovolává svědectví mnoha antických autorů, již ỏeí také vynechávají (J. Whittaker, Timaeus $27 d 5 f f$., str. 181). Důvody pro přidání ócí mohly být, dle

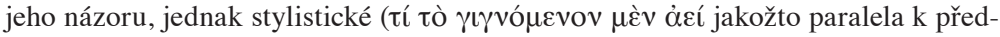

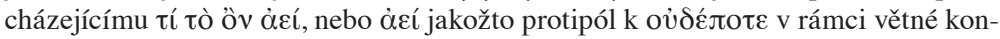
strukce $\mu \varepsilon^{\prime} v-\delta \varepsilon ́$, tamt., str. 182), jednak filosofické (věčně vznikající jakožto argument ve prospěch metaforické interpretace kosmogonie, tamt., str. 184). Možnost věčného vznikání text sice jednoznačně nevylučuje, avšak zároveň nic explicitně nenasvědčuje tomu, že by Timaiova „ontologická diference“ počítala také s touto variantou. Pro podrobnější rozbor tohoto tématu viz následující text.

8 Viz D. Sedley, Creationism and its Critics in Antiquity, str. 97.

9 Srv. pasáž Tim. 48e6, kde je pro stvořený kosmos použit termín $\mu$ í $\mu \eta \mu \alpha$. 
výklad problematiky vzniku kosmu. Poněkud zarážející může být skutečnost, že se tak děje ve velmi stručné a patrně poněkud zjednodušené podobě. Př́ičinou toho může zčásti být Timaiův předem deklarovaný důraz na (pokud možno) co nejsnazší pochopitelnost jeho výkladu (viz Tim. 27d2), zčásti snad také podrobnější rozpracování většiny těchto principů v předešlých Platónových dialozích. ${ }^{10}$ I přesto se však domníváme, že tyto principy jsou v souladu jak s lidským, tak s božským rozumem (viz Timaiovo vzývání bohů v pasáži Tim. 27c1-d4). V průběhu následujícího výkladu bude sice jejich přesný význam dále rozpracováván, resp. uvedené principy budou zásadním způsobem doplněny, nikdy však, dle našeho názoru, nedojde k jejich zásadní revizi či transformaci. ${ }^{11}$

V tomto okamžiku již nic nebrání tomu, aby Timaios znovu explicitně (a v rámci celého dialogu naposledy) formuloval a zodpověděl onu počáteční otázku, zda kosmos byl vždy, a tedy nemá žádný počátek

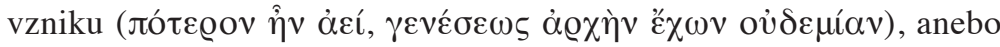

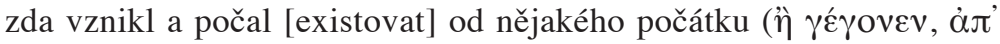

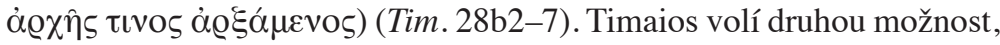

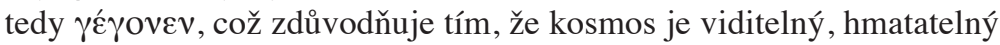

10 Relevantní se v tomto ohledu zdá být především dialog Ústava. Ontologicko-epistemologická rovina je podrobněji rozpracována zejména ve třech centrálních podobenstvích o slunci, úsečce a jeskyni (Resp. 507a1-518b5), pro rovinu mimésis je pak důležitá především úvodní část X. knihy (Resp. 595a1-600c1).

11 Zcela klíčové bude zejména zavedení duše, která se v rámci prooimia nijak nebere v potaz. Duše (byt' vzniklá) nebude jednoduše podřaditelná pod tò

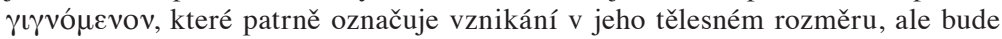
konstituovat samostatnou ontologickou kategorii, jejíž odlišnost bude dána tím, že sdílí charakteristiky obou „světů“ a je schopna oba „světy“ specifickým způsobem propojovat. Tato skutečnost je zřejmá zejména z pasáže Tim. 35a1-4, kde demiurg při tvorbě duše ze stále stejné a nedělitelné jsoucnosti (

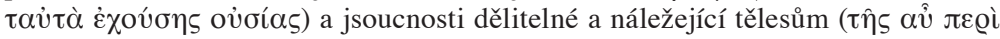

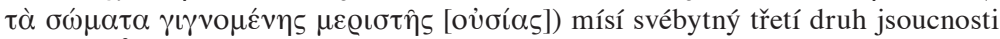

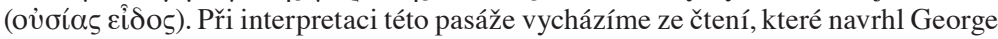
Grube (G. M. A. Grube, The Composition of the World-Soul in Timaeus 35 A-B, in: Classical Philology, 1, 1932, str. 80-82) a k němuž se následně přiklonila naprostá většina badatelů (viz např. F. M. Cornford, Plato's Cosmology: The Timaeus Of Plato (= Plato's Cosmology), Indianapolis - Cambridge 1997, str. 59-66, L. Brisson, Le même et l'autre dans la structure ontologique du Timée de Platon. Un commentaire systématique du Timée de Platon, Sankt Augustin 1998, str. 270-275, T. M. Robinson, Plato's Psychology, Toronto 1995, str. 70-71, nebo T. K. Johansen, Plato's Natural Philosophy. A Study of the Timaeus-Critias (= Plato's Natural Philosophy), Cambridge 2004, str. 138). Pro alternativní interpretaci, kterou s největší pravděpodobností předpokládá také František Novotný ve svém překladu, viz zejm. A. E. Taylor, A Commentary on Plato's Timaeus, str. 106-109. 


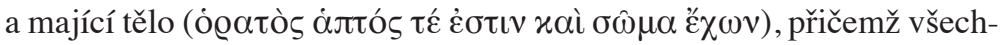
na taková jsoucna jsou smyslově vnímatelná ( $\alpha i \sigma \theta \eta \tau \alpha ́)$ a, jsouce chá-

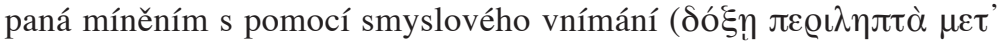

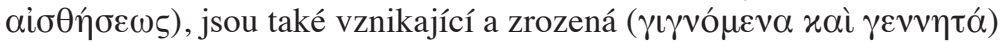
(Tim. 28b7-c2). Z právě uvedeného se tedy nepochybně zdá, že Timai-

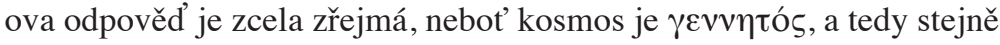
jako ostatní jsoucna spadající do této kategorie neexistoval vždy, ale počal existovat ${ }^{12}$ Přesto však mnozí badatelé z této pasáže vytěžili zcela opačné sdělení, a tak se nyní pokusme prozkoumat důvody, které je k tomuto kroku vedly. Položme si následující otázku: obsahuje Platónův text skutečně tak zjevné indicie, jejichž odhalení nás má vést $\mathrm{k}$ závěru, že smysl textu je ve skutečnosti zcela opačný, než se zdá být na základě prvního dojmu?

Část argumentů skupiny autorů zastávajících metaforický výklad se

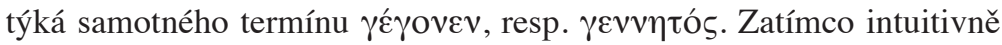
jsou tyto výrazy chápány $\mathrm{v}$ temporálním smyslu, tedy jako výrazy implikující existenci počátku vznikání světa, tito interpreti se je snaží vyložit atemporálně. V tomto duchu již ve 2 . století po Kr. platonik Tauros

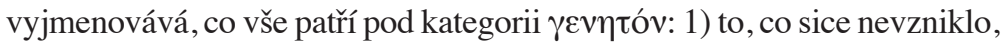

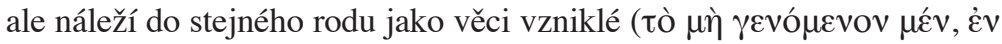

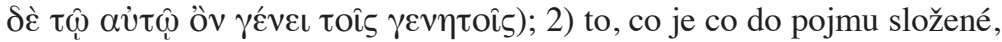

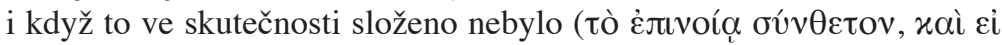
$\mu \eta ̀ ~ \sigma u v \tau \varepsilon \theta \hat{)}) ; 3$ ) to, co je stále v procesu vznikání a mění se jako Próteus

12 Jasně tento prvotní dojem z prooimia zachycuje Thomas Robinson: „But the trenchant ,it has come into being' $(\gamma \dot{\varepsilon} \gamma \mathrm{O} \varepsilon)$ - a statement uttered in advance of any talk about the details of such a coming-into-being or their ,likehood' as details - makes it clear that, unless he is to be accused of near-total confusion in his thinking, Plato meant us to infer from his argument that the world of our acquaintance had a beginning in time." - T. M. Robinson, Plato's Psychology, str. xvi. Z pozdějšího výkladu však bude zřejmé, že nesdílíme Robinsonův názor, že kosmos vznikl v čase, tvrdíme spíše, že vznikl spolu s časem. Srv. taktéž Filoponos, De aet. mund. 125,8-19 a 140,2-14 a D. Sedley, Creationism and its Critics in Antiquity, str. 101. Naopak Martin Ritter se zmíněný argument snaží oslabit tvrzením, že pokud má dokazovat singulární vznik kosmu, je ve skutečnosti neplatný: „Z teze, že to, co vzniká, poznáváme aisthésis, nutně nevyplývá, že to, co poznáváme aisthésis, vzniklo.“- M. Ritter, Konstitutivní rysy Platónova Timaia, in: Reflexe, 29, 2005, str. 23. Autor tak poukazuje na možné slabé místo Timaiovy argumentace, avšak nevysvětluje, proč bychom jej měli vykládat jako Platónovu záměrnou indicii, která má čtenáře vést ke kontraintuitivnímu pochopení smyslu jedné z hlavních tezí prooimia. Pokud bychom Platóna chtěli proti tomuto nařčení bránit, mohli bychom tak učinit oslabením slova غ̇фóvๆ (,,jak se ukázalo“) (Tim. 28c2), které jako jediné indikuje, že by druhá teze měla být důsledkem teze první. 


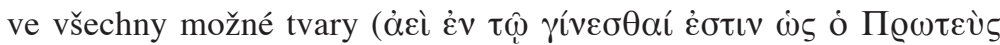

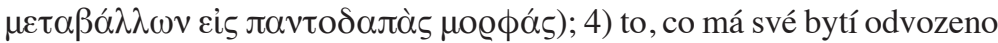

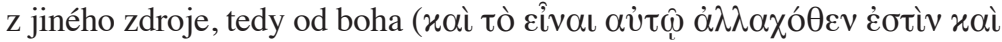

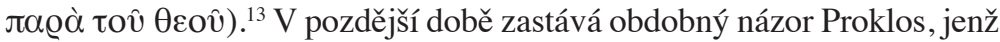
připisuje Platónovi třetí a čtvrtý z těchto významů - domnívá se tedy, že svět je vzniklý v tom smyslu, že jeho bytí spočívá v procesu vznikání a že není sám sobě příčinou, ale je odvozený od boha. ${ }^{14}$ Francis M. Cornford ve 20. století rozlišuje pouze dva významy vzniku, resp. vznikání ( $\gamma \varepsilon ́ v \varepsilon \sigma ı \varsigma, ~ \gamma i ́ \gamma v \varepsilon \sigma \theta \alpha \iota)$, přičemž první značí temporální počátek existence, zatímco druhý znamená bytí v procesu změny. I on sice přiznává, že se na první pohled (,on the surface“) ${ }^{15}$ zdá, že Platón má na mysli temporální význam, avšak v dalším výkladu volí význam druhý, nebot' Platón podle něho staví to, co stále jest, do kontrastu s tím, co stále vzniká, ale nikdy není jsoucí (Tim. 27d5-28a1), což je pro Cornforda dostatečným důvodem, aby uvedenou interpretaci hájil. ${ }^{16}$

O těchto interpretacích lze bezpochyby tvrdit, že nabízejí možný alternativní výklad inkriminované pasáže, avšak nepodávají přesvědčivé důvody, na jejichž základě bychom měli opustit doslovné čtení. Cornfordovo upozornění na kontrast mezi tím, co stále jest, a tím, co stále vzniká, nevyznívá př́liš přesvědčivě, nebot' nejenže smyslově vnímatelná

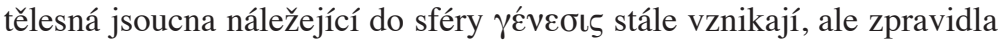

13 Viz Filoponos, De aet. mund. 145,28-147,9.

14 Viz týž, De aet. mund. 148,1-7. V moderní době se ke čtvrtému významu hlásí např. Alfred Taylor - A. E. Taylor, A Commentary on Plato's Timaeus, str. 69.

15 F. M. Cornford, Plato's Cosmology, str. 25.

16 Tamt., str. 24-26. Vidíme tedy, že Cornford zčásti přejímá Proklovo stanovisko a nenabízí skutečně originální argument. Zajímavější je však Cornfordovo srovnání našeho dialogu s Ústavou co do Platónovy narativní strategie. V Ústavě je podle autora ideální obec také představena jakožto vznikající, aniž by však Platón chtěl říci, že nějaká ze skutečných obcí doopravdy vznikla právě takovýmto způsobem (tamt., str. 27). S touto Cornfordovou tezí sice souhlasíme, avšak domníváme se, že srovnání Timaia a Ústavy přinejmenším v několika ohledech nemůže obstát. Zatímco vznik ideální obce je součástí celkového anabaticko-katabatického schématu dialogu, které má zásadní filosofickou důležitost, v Timaiovi na první pohled zcela

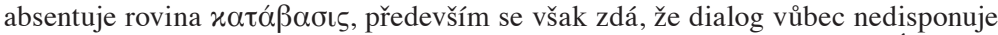
obdobnou dramatickou strukturou. Dále je třeba upozornit, že zatímco v Ústavě je

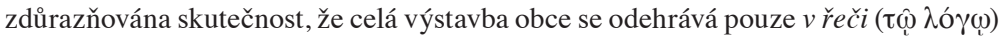
(viz např. Resp. 369c9), v Timaiovi nic nenasvědčuje tomu, že by se nemělo jednat o pokus o upřímný (byt' pouze pravděpodobný) popis reálné kosmogonie, při němž je naopak na vznik kosmu kladen explicitní důraz. K podrobnějšímu rozboru tohoto bodu se dostaneme v průběhu následujícího výkladu. 
počínají také existovat od konkrétního okamžiku. ${ }^{17}$ Již výše jsme podotkli, že v rámci prooimia není nijak tematizována problematika duše,$^{18}$ a tak se zdá, že Timaios zde vznikajícím má na mysli tělesné jakožto tělesné (tzn. tělesný rozměr skutečnosti jako takový). Teprve na základě obecných vlastností tělesných/vznikajících jsoucen ${ }^{19}$ následně vyvozuje určité vlastnosti živých bytostí, jež nutně vyplývají z tělesného aspektu jejich přirozenosti. Až později se dozvídáme, že některé živé bytosti jsou v určitých ohledech a v porovnání s jinými tělesnými jsoucny a bytostmi výjimečné. Timaios však neopomene tuto jejich výjimečnost explicitně zdůraznit (jedná se především o skutečnost, že kosmos, ani ostatní bohové nikdy nezaniknou, i přesto, že mají tělesnou přirozenost - viz Tim. 41a8-b6, Tim. 32c1-4 a 32c5-33b1 v kombinaci s Tim. 30a6-7). Pokud by kosmos (a snad také ostatní božské bytosti) měl být „pouze“ věčně vznikající, ale ve skutečnosti nikdy nevzniklý, Timaios by tuto výjimečnou skutečnost měl zdůraznit stejně explicitním způsobem, aby jeho výklad nepůsobil matoucím dojmem. K ničemu takovému však nikde v dialogu nedochází.

Rovněž se domníváme, že je nutno věnovat zvýšenou pozornost přesné formulaci oněch dvou alternativ předcházejících Timaiově odpovědi:

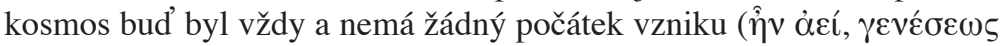

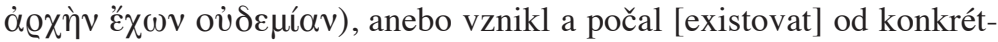

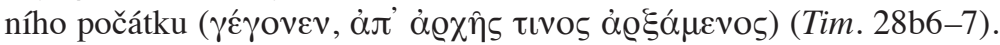
O domnělém jsoucnu, jež by neustále vznikalo, ale nepočalo vznikat od konkrétního počátku, před nímž by neexistovalo, bychom mohli spíše

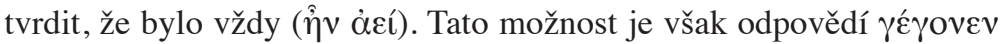
zcela jednoznačně a nade vši pochybnost vyloučena. Jsme tedy přesvědčeni, že Platón v inkriminovaném textu čtenáři skutečně neposkytuje zásadní indicie vedoucí k domněnce, že nabízející se reálnou interpretaci je

17 Cornfordův argument navíc částečně oslabuje pochybný status slova ỏeí v místě Tim. 28a1 (srv. výše, pozn. 7).

18 Viz výše, pozn. 11.

19 S ohledem na problematiku vzniku se jedná zejména o to, že tato jsoucna vznikají v konkrétním okamžiku, během své existence se nacházejí v procesu neustálého vznikání (a zanikání), a po určité době jakožto celky zanikají. Viz ze-

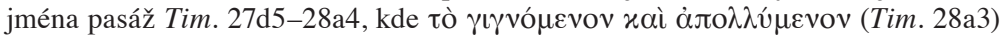
navrhujeme chápat ve dvojím smyslu: jednak jako neustálé vznikání a zanikání co do částí a jednak jako singulární vznik a zánik co do celku každého jednotlivého tělesného jsoucna. 
třeba odmítnout a uchýlit se k interpretaci metaforické. ${ }^{20}$ Naopak již výše jsme viděli, že je kladen důraz na jasnost a co možná nejsnazší pochopitelnost následného výkladu (Tim. 27d2). Gregory Vlastos tak oprávněně tvrdí, že pokud by Platón za této situace chtěl do svého textu skutečně vložit sdělení, že kosmos je „pouze“ věčně vznikající, ale ve skutečnosti nikdy nevzniklý, rovnal by se jeho postup záměrné mystifikaci čtenáře. ${ }^{21}$

Ještě jiný typ argumentu ve prospěch metaforické interpretace nabízí Matthias Baltes. ${ }^{22}$ Dle jeho názoru by Platón, maje na mysli singulární vznik kosmu, použil jiné slovesné časy. Velice stručně shrnuto, ono klíčové slovo jednoznačně vypovídající o vzniku světa by, dle Balte-

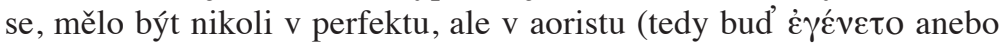

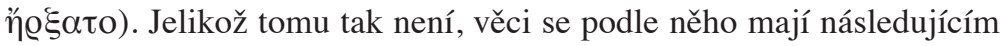
způsobem: cílem již zmíněného protikladu není zodpovědět otázku, zda kosmos vznikl, či nikoli, ale zda je vždy jsoucí, anebo výsledkem jistého

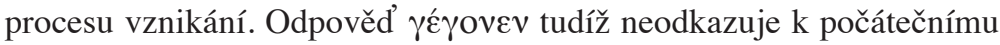
okamžiku vzniku, ale zařazuje svět mezi jsoucna druhého typu. Baltes

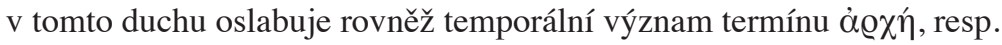
participia $\alpha \varrho \xi \alpha_{\alpha} \mu \varepsilon v o \varsigma$. Dle jeho názoru je klíčové přidání neurčitého zá-

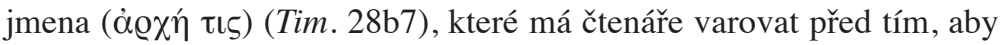

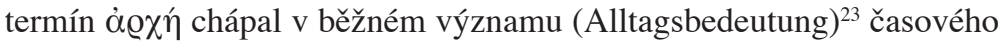
počátku. $\mathrm{V}$ jeho pojetí tedy Platón chce říct pouze to, že $\mathrm{v}$ základu sou-

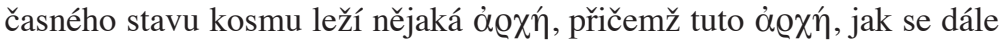

20 Všimněme si také, že zatímco metaforická interpretace prooimia reálnou variantu vylučuje, reálná interpretace teze metaforického výkladu - přinejmenším ty základní - zahrnuje, avšak nepokládá je za hlavní sdělení inkriminované pasáže. I přes primární důraz na singulární vznik kosmu tedy v žádném případě nechceme popírat, že bytí světa je podle Timaia bytím v procesu neustálé změny, resp. neustálého vznikání (a zanikání), a že svět podle něho není sám příčinou svého bytí, nýbrž že je v určitém smyslu odvozený od boha.

21 G. Vlastos, Creation in the Timaeus: Is it a Fiction? (= Creation in the Timaeus), in: týž, Studies in Greek Philosophy, II, Socrates, Plato, and their Tradition, vyd. D. W. Graham, Princeton 1995, str. 268-269. Srv. taktéž důležitý postřeh Sarah Broadiové, která upozorňuje, že v intelektuálním kontextu před-platónské filosofie byla hypotéza vzniku kosmu něčím obvyklým a hypotéza jeho věčného trvání naopak novinkou. Bylo by tedy krajně zvláštní, pokud by Platón chtěl uvést takto originální myšlenku a přitom to učinil tak matoucím a nejednoznačným způsobem (S. Broadie, Nature and Divinity in Plato's Timaeus, Cambridge 2012, str. 245-246).

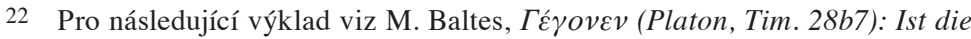
Welt real entstanden oder nicht? $(=\Gamma \dot{\gamma} \gamma o v \varepsilon v)$, in: K. A. Algra $-\mathrm{P}$. W. van der Horst D. T. Runia, Polyhistor: Studies in the History and Historiography of Ancient Philosophy, Leiden - New York - Köln 1996, str. 92-94.

23 Tamt., str. 93. 
dozvídáme, je třeba chápat spíše v ontologickém smyslu a její působení lze rozložit do tří aspektů: jeden aktivně tvůrčí, další pořádající a poslední paradigmatický.

Ani tento typ argumentace ovšem nepovažujeme za dostatečný pro odmítnutí intuitivní reálné interpretace. Na rozdíl od Baltese se domníváme, že pro vyjádření singulárního vzniku kosmu je kombinace slovesa

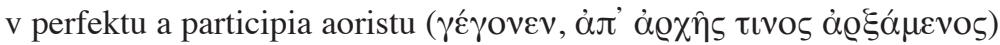
zcela přiléhavá. Perfektum standardně označuje děj, jenž započal i skončil v minulosti, avšak jehož následek je permanentní. ${ }^{24}$ Doslovně bychom

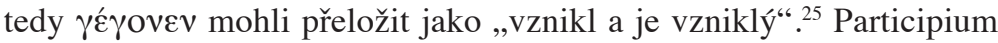
v aoristu pak tvoří vhodný doplněk, nebot' explicitně vyzdvihuje sdělení implicitně obsažené již v perfektu. Svět tak vznikl a stále trvá, ale fakt, že započal od konkrétního počátku, je čistě záležitostí již minulého okamžiku, proto aorist indikující dokonavost. ${ }^{26}$ Jsme přesvědčeni,

24 Viz H. W. Smyth, A Greek Grammar for Colleges, Woodstock 1920, §1852b. Zajímavý je v tomto ohledu Filoponův odkaz na pasáž z dialogu Zákony, v níž Platón používá velmi podobnou terminologii - viz Filoponos, De aet. mund. 162,5-14. Jedná se o následující text: „Tolik musí dobře uznat každý člověk, že lidské pokolení bud’ vůbec nemá žádného počátku a nikdy nebude mít konec, nýbrž vždy napořád

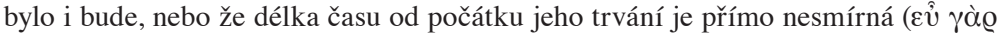

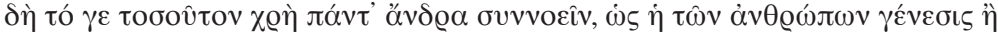

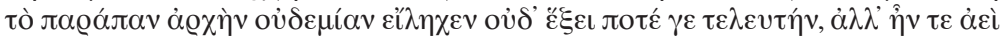

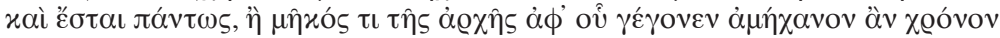

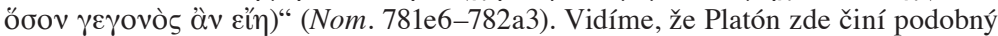
kontrast jako v dialogu Timaios: na jednu stranu staví to, co vždy bylo a bude a nemá

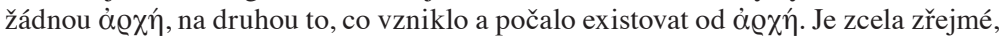
že pojem $\alpha \varrho \chi \eta ́ j$ je tu použit ve smyslu časového počátku a že sloveso $\gamma \dot{\varepsilon} \gamma o v \varepsilon v$, jež se k němu váže, zde implikuje představu konkrétního minulého okamžiku, od něhož počalo lidské pokolení existovat, a bylo by neobyčejně zvláštní, pokud by Platón ve dvou různých dialozích používal v podstatě tutéž terminologii, avšak pokaždé ve zcela odlišném smyslu, resp. k vyjádření odlišné myšlenky. David Sedley pak neméně výmluvně odkazuje na úvod dialogu Kritias (Crit. 106a3-4), kde se Timaios

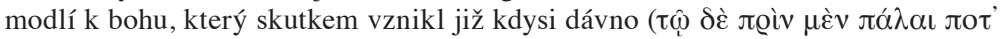

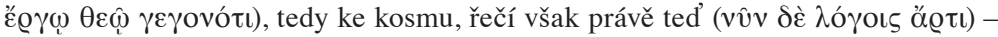
D. Sedley, Creationism and its Critics in Antiquity, str. 102. Stejně jako není pochyb o tom, že Timaiova řeč vznikla v určité době, před níž neexistovala, nemůže být na základě tohoto sdělení pochyb ani o tom, že totéž platí i pro kosmos.

25 Nebo alternativně také ,,vznikl a je vznikající“. Jak jsme již řekli výše, reálný výklad prooimia hlavní teze metaforické interpretace prakticky nijak nevylučuje. I v této verzi by však v našem pojetí měla být jasně patrná distinkce mezi počátkem vzniku a jeho následkem, tzn. od té doby trvajícím procesem vznikání/dění/měnění se.

26 Platónovo použití slovesných časů dlouze obhajuje také Jan Filoponos - viz Filoponos, De aet. mund. 161,5-171,20. 
že ani zájmeno tıৎ tuto skutečnost nijak neoslabuje, nýbrž pouze ukazuje na jeho nepř́ístupnost, a tudíž neurčitost. Timaios nám tak sděluje, že kosmos počal existovat od jakéhosi počátku, protože o tomto počátku není schopen ze své pozice konečné lidské bytosti podat náležitý výklad. Jedná se totiž také o samotný počátek času, a nikoli o okamžik, který by se, stejně jako jiné změny, udál $v$ čase (viz Tim. 38b6). Neshledáváme tedy

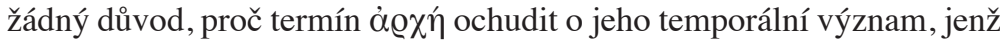
jde s Timaiovým sdělením velmi dobře dohromady a je intuitivně zřejmý.

Dokonce existuje jeden důvod, proč bychom měli Baltesovu interpretaci tohoto problému odmítnout. Je sice nepochybně pravdou, že ter-

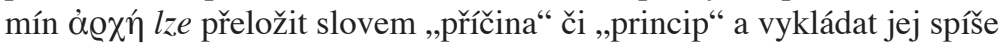
ontologicky než temporálně, avšak stojí za povšimnutí, že Platón v pro-

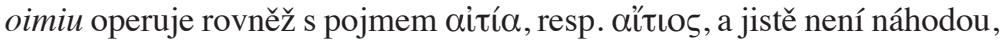
že se tak děje právě v kontextu, v němž temporální význam nepřichází

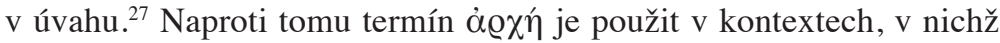
je temporální aspekt jeho významu zcela zř́ejmý ${ }^{28}$ nebo v nichž přinejmenším nemůže být vyloučen. ${ }^{29}$ Pokud bychom tedy chtěli i nadále hájit

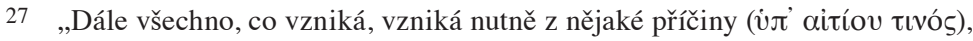

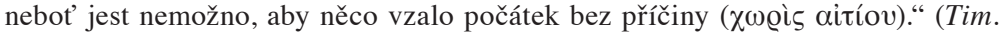
28a4-6) „Ale co vzniklo, řekli jsme, že nutně vzniklo z nějaké příčiny (ivं airíov

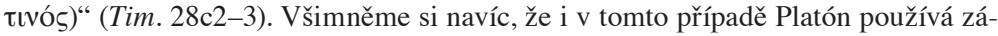
jmeno $\tau \iota \varsigma$, avšak zde je ona neurčitost a nespecifikovatelnost zcela zřejmá a ihned objasněná následující větou: „Tvůrce však a otce tohoto všehomíra nalézti by bylo trudno, a kdybychom ho nalezli, nemožno všem jej zvěstovati.“ (Tim. 28c3-5) Můžeme se tedy odvážit tvrzení, že tato skutečnost podporuje naši výše podanou inter-

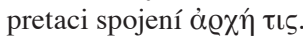

$28, \ldots$ o něm jest nejprve uvážiti to, co musí být předmětem počáteční úvahy při

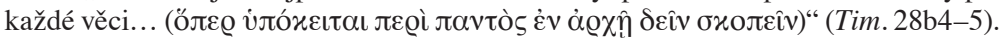

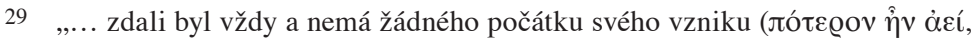

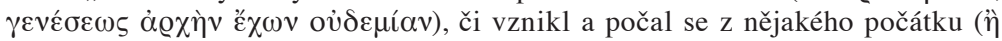

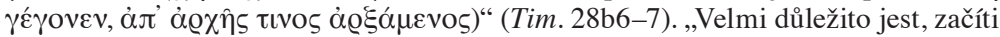

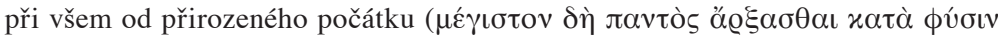

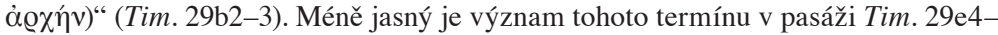
-30a2, která ale již není součástí prooimia: „Kdokoli by tedy slyšel od mužů rozumných, že takový právě byl vlastní počátek stvoření a světa, mohl by tomu zcela správ-

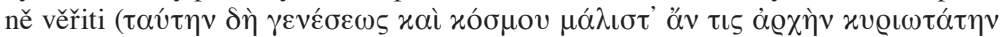

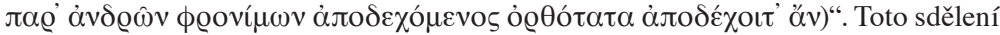
následuje bezprostředně po uvedení demiurga, který, jsa prost závisti, chtěl, aby se

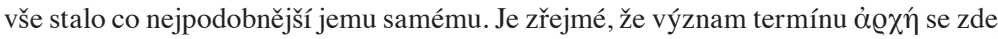

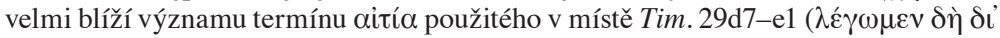

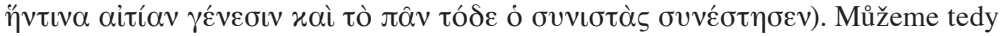
tvrdit, že v této pasáži Platón již nedrží tak jasnou distinkci mezi oběma termíny jako v rámci prooimia, anebo se můžeme i v tomto př́ípadě pokusit nalézt tentýž 
Baltesův výklad tohoto problému, museli bychom tvrdit, že Platón při-

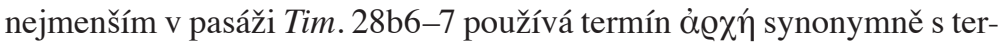

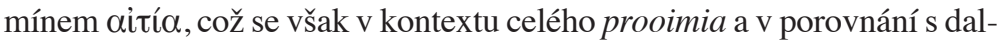
šími relevantními výskyty jeví jako nepravděpodobné. ${ }^{30}$ Plausibilnějším vysvětlením, které se intuitivně nabízí, je, že přinejmenším v rámci

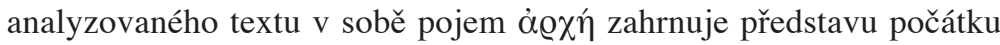
existence kosmu, zatímco pojem aĩía odkazuje k př́čině jeho vzniku. ${ }^{31}$

\section{Kosmos jakožto eixú́v}

Ve zbylé části prooimia (Tim. 29a2-29d3) Timaios dále tvrdí, že tvůrce

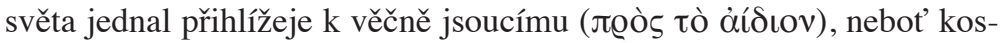

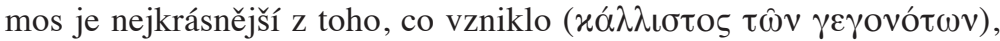

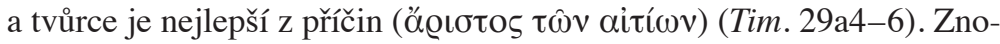
vu se nám tedy potvrzuje již výše řečené: 1) kosmos náleží do stejné ontologické kategorie jako jiná vzniklá jsoucna (viz plurál partitivního genitivu $\tau \hat{\omega} v \gamma \varepsilon \gamma o v o ́ \tau \omega v)$, a tudíž máme důvod se domnívat, že by pro něj měly platit tytéž charakteristiky, jež platí pro ně; ${ }^{32} 2$ ) pro tvůrce kosmu Platón znovu konsistentně používá termín aitía, zatímco termín

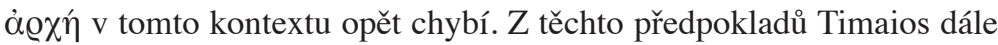

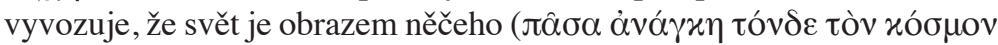

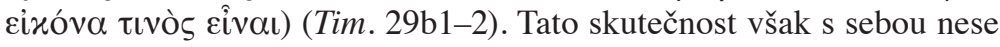
zásadní implikace pro Timaiův následující výklad, nebot' slova jsou sou-

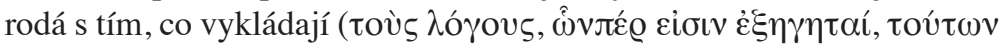

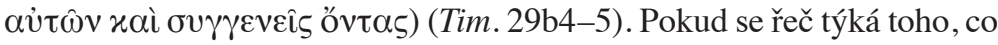

rozdíl. Pokud bychom zvolili druhý přístup, mohli bychom demiurgovu dobrotu a absenci závisti pochopit jako vlastní př́činu stvoření, zatímco o jeho chtění, jež je prezentováno nikoli jako základní premisa, ale jako vyplývající z absence závisti

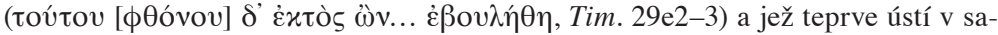
motný stvořitelský akt, bychom mohli hovořit jako o samotném počátku stvoření. Je však zřejmé, že i za tohoto předpokladu se jedná spíše o dvě odlišné strany téže mince, než o skutečně zásadní rozdíl.

30 Srv. Filoponos, De aet. mund. 182,27-186,6.

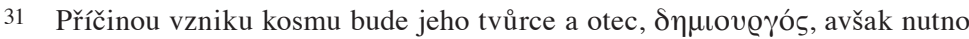
připomenout již výše řečené, a sice že v této pasáži operuje Platón s termínem dití $\alpha$ na obecnější rovině jakožto s př́íčinou jakékoli vzniklé věci.

32 Že se nejedná o všechny charakteristiky, je zřejmé již z výše podaného výkladu, v němž jsme se pokusili ukázat, že výjimečnost kosmu spočívá zejména v tom, že i přes to, že je stvořený, nikdy nedojde zániku. Timaios však tuto výjimku neopomíjí náležitým způsobem zdůraznit. 


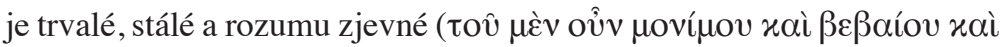

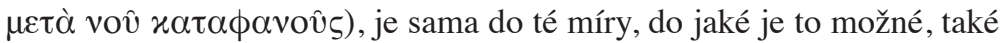
taková, tedy trvalá a nevývratná (Tim. 29b5-c1). Pokud se ovšem týká vytvořeného obrazu, který charakteristiky trvalosti, stálosti a zjevnosti rozumu postrádá, ona řeč již z principu nemůže být trvalá a nevývrat-

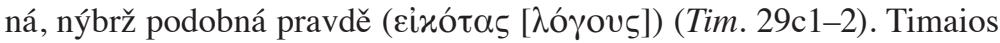
tento nesnadný výklad dále objasňuje následujícím poměrem: vzniká-

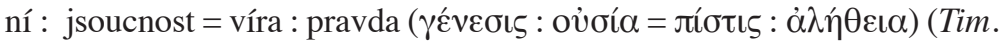
29c3). Zdá se tedy, že mezi ontologickou a epistemologickou rovinou existuje jistá korespondence, jež nám zároveň ukazuje, jaké nároky lze klást na tu či onu řeč a podle jakých standardů má být poměřována. Zatímco v případě trvalých jsoucen je namístě požadovat řeč pravdivou a nevývratnou, v př́padě věcí, jež jsou jejich obrazem, by takovýto nárok byl pošetilý a nerozumný.

V závěru prooimia Timaios vztáhne právě řečené na svůj vlastní výklad. Jeho řeč bude moci operovat nikoli na rovině $\alpha \hat{\eta} \eta \dot{\theta} \varepsilon \alpha$, nýbrž na rovině $\pi i ́ \sigma \tau ı \varsigma$, protože jejím předmětem bude kosmos, jenž náleží nikoli do sféry oưoí $\alpha$, ale $\gamma \varepsilon ́ v \varepsilon \sigma ı \varsigma . Z$ tohoto důvodu Timaios explicitně varuje své posluchače (a jeho ústy samozřejmě Platón své čtenáře), aby na následující řeč nekladli nerozumné nároky. Explicitně upozorňuje na fakt, že nebude možno podat řeči ve všem všudy vnitřně souladné

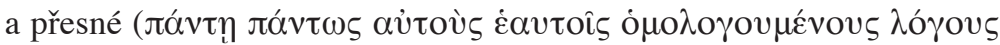

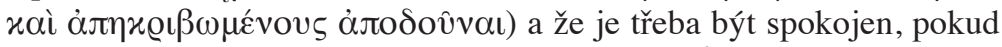

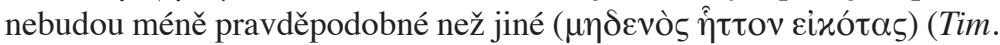
29c4-8). Jak uvidíme v dalším výkladu, toto Timaiovo upozornění je naprosto klíčové pro celý zbytek dialogu a pro jeho správné pochopení bude nezbytné mít jej stále na paměti. Na samotném konci prooimia Timaios tento svůj závěr podpoří ještě odkazem jak na svou lidskou přirozenost ( $\dot{\alpha} v \theta \varrho \omega \pi i ́ v \eta \phi v ́ \sigma \iota \varsigma)$, tak na lidskou přirozenost svých posuzovatelů. Z tohoto důvodu se sluší ( $\pi \varrho \varepsilon ́ \pi \varepsilon \iota)$, aby všichni zúčastnění

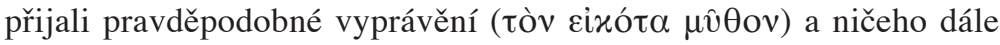
nevyhledávali (Tim. 29c8-d3). ${ }^{33}$ Timaiova kvalifikace následující řeči výrazem عixùs $\mu \hat{\theta} \theta$ os je však natolik důležitou skutečností, že bude potřeba ji podrobně rozebrat v následující kapitole.

33 Nabízí se otázka, zda i předchozí výklad byl činěn pouze z pozice lidské bytosti, a zda je tudíž bůh schopen vyložit pravdu i o věcech náležejících do sféry

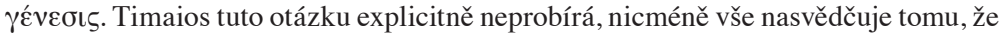
bůh by sice byl schopen dosáhnout větší pravděpodobnosti než lidská bytost, avšak v principu by se jeho výklad pohyboval na téže rovině (srv. níže, pozn. 56). 


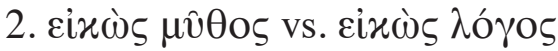

Jaké důsledky je tak třeba vyvodit $\mathrm{z}$ toho, že Timaios celou svoji řeč hned zpočátku označuje za عixùs $\mu \hat{\theta} \theta$ os, tedy doslova za ,pravděpodobný mýtus“ či „,pravděpodobné vypravování“? ?34 Podívejme se za tímto účelem ještě jednou na výše probíranou pasáž:

„Jestliže tedy, Sókrate, o mnohých jsoucnech, o bozích a vzniku všehomíra nebudeme schopni podat řečí ( $\lambda$ ó ov $)$ ve všem všudy vnitřně souladných a přesných, nediv se; než bud'me spokojeni, předneseme-li řeči, které nebudou méně pravděpodobné, než jiné

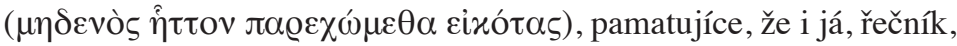

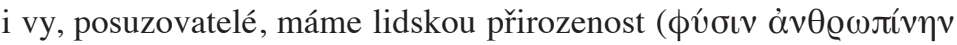

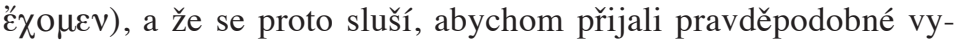

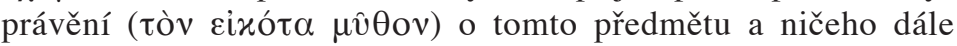
nevyhledávali.“ 35

Oproti intuitivní snaze o vyzdvižení klasického kontrastu $\mu \hat{\theta} \theta$ o vs. $\lambda$ ó 05 , jež vede k tomu, že je kladen důraz na bytostně mythický, a tudíž ,nevědecký“ charakter Timaiova vypravování, ${ }^{36}$ vystupují badatelé, kteří zdůrazňují termín eixós, jenž naopak vyzdvihuje jeho pravděpodobnost..$^{37}$ Tato snaha má své oprávnění, nebot' v průběhu Timaiovy řeči

34 Druhý typ překladu je obvyklejší - jeho varianty můžeme nalézt např. u Cornforda (,story“), Lamba (,,account“) či Novotného (,výklad“). Proti tomuto čtení však explicitně vystupuje Myles Burnyeat ve své vlivné studii $E I K \Omega \Sigma M Y \Theta O \Sigma$. Dle jeho názoru je adekvátnějším překladem „mýtus“ (myth), nebot’ Timaiova řeč splňuje následující charakteristiku: činí důležité odkazy k božské rovině a nemá charakter prostého historického popisu proběhnuvších událostí. Termín $\mu$ v̂ $\theta$ ऽ ve smyslu „myth“ se prý navíc vyskytuje o pouhé tři Stephanovy strany dříve a není důvod se domnívat, že Platón v naší pasáži Tim. 29d2 jeho význam mění (M. Burnyeat, EIK $\Omega \Sigma M Y \Theta O \Sigma$, in: Rhizai, 2, 2005, str. 144).

35 Platón, Tim. 29c4-d3, in: Platón, Spisy, I-V, přel. F. Novotný, Praha 2003 (překlad mírně upraven).

36 Do této skupiny bychom snad mohli zařadit Francise Cornforda, podle něhož termín eỉxós indikuje pouze to, že Timaiovo vyprávění není úplně nepravdivé, a, jak se zdá, větší důraz klade na výraz $\mu$ v̂os, jenž má poukazovat na nemožnost vědeckého uchopení materiálního světa, avšak navíc také na fakt, že celá kosmogonie je prezentována jako sled jednotlivých, časově návazných událostí (F. M. Cornford, Plato's Cosmology, str. 30-31).

37 Za všechny zmiňme např́íklad Gregoryho Vlastose či Mylese Burnyeata, jejichž interpretacím se budeme věnovat níže. 
se rovněž několikrát objevuje spojení cixùs $\lambda o ́ \gamma o \varsigma$ (implicitně dokonce i v právě citované pasáži), což by pro interpretaci zdůrazňující mythický charakter následující řeči mohlo představovat určitý problém. Takto např. Gregory Vlastos upozorňuje na jedinečné postavení Timaiova mýtu v kontextu ostatních platónských mýtů z jiných dialogů a se zmíněným důrazem na termín eixú́ o něm mluví jako o „vědeckém mýtu“ (scientific myth), ${ }^{38}$ jehož každou část musíme pokládat za pravděpodobnou, pokud nemáme jiné indicie, jež by nás vedly k opačnému názoru. To, že tato pravděpodobnost nemůže být úplnou jistotou, je podle Vlastose dáno ontologickou distinkcí mezi věčnými idejemi a jejich pomíjivými kopiemi, která, jak jsme již viděli, implikuje epistemologickou distinkci mezi jistotou a pravděpodobností. ${ }^{39}$

Myles Burnyeat nicméně k této otázce dodává, že kromě zmíněného

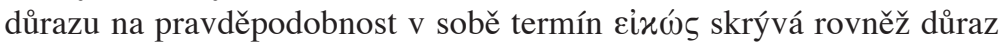
na „náležitost“ či „rozumnost“ dané řeči či daného názoru. ${ }^{40}$ Kvalifikace

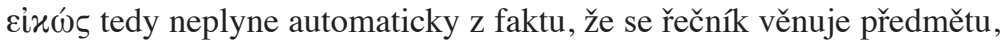

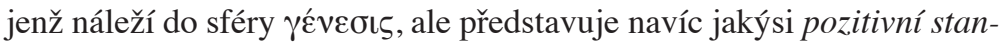
dard, kterému lze dostát a podle něhož je možno následně řeč posuzovat. Timaios prý tohoto standardu dosahuje proto, že jeho vyprávění překonává tradiční kontrast mezi theogonií hésiodovského typu a „vědeckými““

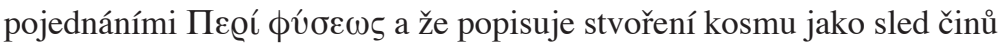
plynoucích z demiurgovy rozumné praktické úvahy (practical reasoning).$^{41}$

38 G. Vlastos, Disorderly Motion in Plato's Timaeus, in: týž, Studies in Greek Philosophy, II, str. 248.

39 Tamt., str. 248-250.

40 Zdá se však, že rozumnost a pravděpodobnost vypravování ve skutečnosti splývají, nebot' pokud je tvůrce kosmu dobrý a pokud je přesvědčen, že rozumné jsoucno bude vždy lepší než nerozumné, pak platí, že čím rozumnější naše řeč bude, tím bude pravděpodobnější, že odpovídá skutečnosti (srv. M. Burnyeat, $E I K \Omega \Sigma$ $M Y \Theta O \Sigma$, str. 156).

41 Tamt., str. 145-146, 150, 156, 158-160. Je však třeba zdůraznit, že omeze-

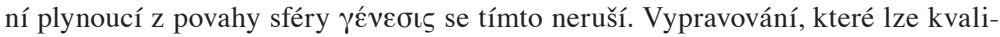
fikovat jako cixús, se tedy nepochybně pohybuje v rámci jistých omezení, avšak $v$ rámci těchto omezení musí zároveň dostát určitému pozitivnímu standardu. Oba faktory jsou tak spíše kompatibilní, resp. koexistující, a nikoli vzájemně exklusivní, jak správně upozorňuje Gábor Betegh - viz G. Betegh, What Makes a Myth eikós? Remarks Inspired by Myles Burnyeat's EIK $\Omega \Sigma M Y \Theta O \Sigma$, in: R. D. Mohr - B. M. Sattler (vyd.), One Book, The Whole Universe. Plato's Timaeus Today, Las Vegas Zurich - Athens 2010, str. 214. Betegh dále dodává, že ,úspěšnost“ pravděpodobného vypravování se nezvyšuje, pouze pokud je rozumné či náležité, ale také pokud svůj předmět adekvátně prezentuje jakožto cixúv, tedy pokud vysvětluje, jaký je jeho model, proč byl vytvořen právě podle tohoto modelu, kým atd. (tamt., str. 218). 
Z tohoto důvodu Burnyeat také odmítá tendence, jež se snaží pravděpodobnost Timaiovy řeči spíše oslabit. ${ }^{42}$

Domníváme se, že tento důraz na termín eixús, jenž, jak jsme se pokusili naznačit, na jedné straně zachycuje jisté omezení plynoucí z povahy předmětu Timaiova výkladu, avšak zároveň vyzdvihuje i jeho pravděpodobnost (a rozumnost či náležitost), tzn. představuje jistý pozitivní standard, je oprávněný, avšak je třeba přezkoumat, zda je př́ípustná nivelizace tradičního rozdílu mezi mythem a logem, které se ve svém výkladu dopouští např. Vlastos ${ }^{43}$ Ze současných badatelů se tomuto problému nejpodrobněji věnuje Thomas Johansen, ${ }^{44}$ který na základě komparace s druhou knihou Ústavy konstatuje, že rozdíl mezi mythem a logem nemá u Platóna tak jednoduchou podobu, jak by se na první pohled mohlo zdát. V pasáži Resp. 376e-377a se dozvídáme, že existují dva typy logů - jeden pravdivý, druhý nepravdivý, přičemž tento druhý typ bude nadále označován jako $\mu \hat{v} \theta 0 \varsigma .^{45} \Lambda$ ó $\gamma$ o tedy prý můžeme pochopit v zásadě dvojím způsobem: jednak jako obecnější kategorii, jež v sobě zahrnuje druh řečí pravdivých i nepravdivých, a jednak jako specifický

42 Viz např. Novotného překlad: „... bud’me spokojeni, předneseme-li řeči alespoň podobné pravdě, pamatujíce, že i já, řečník, i vy, posuzovatelé, jsme jenom lidé..." (Tim. 29c8-d1, kursiva J. S.). V této kritice s Burnyeatem plně souhlasí také Gábor Betegh (viz G. Betegh, What Makes a Myth eikós?, str. 214).

43 Ke kritice Vlastose odvíjející se od tohoto problému viz T. K. Johansen, Plato's Natural Philosophy, str. 62.

44 Viz tamt., str. 48-68.

45 Johansen však upozorňuje, že toto tvrzení neznamená, že všechny mýty musí nutně být nepravdivé. Klíčovým faktorem je totiž naše neznalost minulých událostí, o nichž mýty vyprávějí. Pointa je tedy v tom, že na rozdíl od logů nemůžeme v případě mýtů dokázat ani vyvrátit jejich faktickou pravdivost či nepravdivost, a právě toto je jeden z důvodů, proč jsou označovány adjektivem $\psi \varepsilon v \delta \hat{\eta ~(v i z ~ t a m t ., ~ s t r . ~ 66) . ~ J e ~}$ však třeba zdůraznit, že rovinou faktickou se tento problém nevyčerpává, nebot' pro Platóna je mnohem důležitější rovina etická či morální. Podle Stephena Halliwella Platónovi o rovinu faktické pravdivosti dokonce ani příliš nejde - viz S. Halliwell, The Aesthetics of Mimesis. Ancient Texts and Modern Problems, Princeton 2002, str. 50, pozn. 33. Pravdivost na etické rovině je pak dána správným ztělesněním obecných morálních principů. Pokud tedy Homér vypráví nap̌r. o kastraci Krona Diem, je tento příběh nepravdivý primárně na rovině etické a teprve od této roviny se následně odvíjí jeho nutná nepravdivost také na rovině faktické. Jiné příběhy naopak mohou být na etické rovině pravdivé, i když na faktické rovině jsou nepravdivé, resp. jejich faktická pravdivost není dokazatelná. Můžeme se tedy přiklonit k tvrzení Normana Gulleyho, jenž u Platóna rozlišuje mezi pravdivými fikcemi a lživými fikcemi - viz N. Gulley, Plato on Poetry, in: Greece \& Rome, 2, 1977, str. 163. Na rovině faktické jsou sice všechny mýty přinejmenším nedokazatelné, avšak na rovině etické v jejich rámci můžeme i přesto odlišovat pravdivé od nepravdivých. 
poddruh zahrnující pouze řeči pravdivé. Jinými slovy: k rozdílu $\mu$ v̂

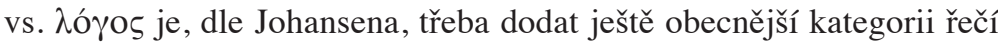
jako takových, pro niž však Platón používá rovněž termín $\lambda$ ó $\gamma 0 \varsigma .{ }^{46}$ Nutno však dodat, že při tomto rozdělování se neustále pohybujeme v rovině pravděpodobnosti. I v onom obecnějším významu tak máme stá-

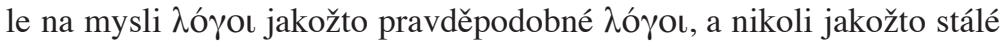
a nevývratné. ${ }^{47}$ Tento výklad si pro větší přehlednost můžeme shrnout v následující tabulce:

\begin{tabular}{|c|c|}
\hline Rovina pravdy & Rovina pravděpodobnosti \\
\hline$\lambda$ ó $\gamma \mathrm{o \iota}$ & $\lambda$ ó $\gamma \mathrm{o \iota}$ \\
\hline & $\lambda$ ó $\gamma \mathrm{ol}$ vs. $\mu \hat{v} \theta \mathrm{o \iota}$ \\
\hline
\end{tabular}

Pokud se vrátíme zpět k dialogu Timaios, můžeme konstatovat, že

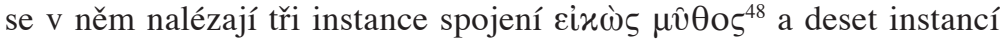
spojení cixùs $\lambda o ́$ os ${ }^{49}$ Dle Johansenovy teze spočívá rozdíl v tom, že $\mu v ̂ \theta o \varsigma$ vždy nějak souvisí s důrazem na omezení plynoucí z naší lidské přirozenosti, zatímco $\lambda o ́$ os označuje bud’ onu obecnější kategorii pravděpodobných řečí jako takových, anebo se (v užším významu chápaném jako protipól mythu) druží k tezím, jež nesouvisejí s lidskou přirozeností, a tudíž jsou ve výsledku pravděpodobnější než ty, k nimž se druží $\mu v \hat{\theta o s} .{ }^{50}$ Hlavním nedostatkem Johansenovy interpretace je však to, že analyzuje pouze ony tři výskyty spojení cixòs $\mu \hat{\theta} \theta$ o a výskytům

\footnotetext{
46 T. K. Johansen, Plato's Natural Philosophy, str. 65.

47 Že však Platón s rovinou jistých a nevývratných logů taktéž počítá, je předvedeno v pasážích Tim. 29b5-7, kde čteme, že „slova o trvalém a stálém a rozumem objevovaném jsou trvalá a nevývratná“, a Tim. 29c4-7, kde Timaios varuje Sókrata, aby se nedivil, pokud „o mnohých jsoucnech, o bozích a vzniku všehomíra nebudeme schopni podat řečí ve všem všudy vnitřně souladných a přesných“. Tato jistota a nevývratnost však obdobně jako v případě termínu eixús označuje určitý pozitivní standard, jemuž lze dostát, a Platón jistě nechce tvrdit, že pokud bude kdokoli hovořit o jsoucnech „trvalých a rozumem objevovaných“, jeho řeč bude automaticky jistá a nevývratná (viz M. Burnyeat, $E I K \Omega \Sigma M Y \Theta O \Sigma$, str. 150). Jak však vyplývá z poslední uvedené citace, rovina jistoty v našem dialogu nehraje významnější roli, nebot' celý Timaiův výklad se týká kosmu, a tudíž se pohybuje na rovině pravděpodobnosti. $\mathrm{Z}$ tohoto důvodu se ji nebudeme snažit blíže tematizovat.
}

48 Tim. 29d2, 59c6, 68d2.

49 Tim. 29c8, 30b7, 48d2, 53d5-6, 55d5, 56a1, 57d6, 59d1, 68b7, 90e8.

50 T. K. Johansen, Plato's Natural Philosophy, str. 62-64. 
spojení عixùs $\lambda o ́ \gamma o \varsigma$ se nijak nevěnuje. Pokusme se tedy tuto práci vykonat sami, abychom viděli, zda Johansenova poměrně komplikovaná teze obstojí, či nikoli.

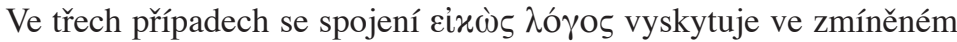
obecnějším smyslu označujícím kategorii pravděpodobných řečí jako takových, které lze postavit do kontrastu vůči řečem spadajícím do roviny jistoty. ${ }^{51}$ Pro potřeby posouzení Johansenovy interpretace je však důležitější uvést pasáže, kde nalézáme spojení cixòs $\lambda o ́ \gamma o \varsigma$ v užším smyslu, tedy jako poddruh obecné kategorie řečí pravděpodobných, ve kterém by mělo tvořit alespoň dílčí kontrast vưči દixòs $\mu \hat{\theta} \theta$ os. Nejpočetnější skupinu tvoří pasáže obsažené v Timaiově matematicko-přírodovědném výkladu o podílu nutnosti na vzniku kosmu. V rámci pravděpodobného logu se tak dozvídáme o počátku ohně z trojúhelníků (Tim. 53d5-6), o tom, že prvek země má tvar krychle (Tim. 56a1), či o nekonečné rozmanitosti bohem stvořených trojúhelníků, kterou je třeba pozorovat, chceme-li bádat o přírodě právě po způsobu pravděpodobného logu (Tim. 57d6). V pasáži Tim. 30b7 se z obecnějších (nejen) etických premis dojde k závěru, že dle pravděpodobného logu je třeba tvrdit ( $x \alpha \tau$ ò

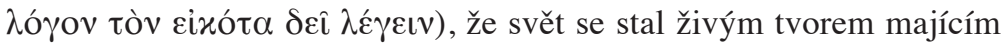
duši a rozum. V místě Tim. 55d5 čteme, jak podle našeho výkladu stvořil bůh pravděpodobně jeden svět, a konečně v poslední pasáži Tim. $90 \mathrm{e} 8$ se dozvídáme, že ze zbabělých a nespravedlivých mužů z prvního lidského pokolení se při druhém zrození staly ženy. ${ }^{52}$

S těmito pasážemi se nyní pokusme kontrastovat Johansenem analyzované tři výskyty spojení cixòs $\mu \hat{\theta} \theta$ os. Zdá se, že dva z nich jsou opravdu v souladu s jeho tezí o souvislosti mythu s odkazem na omezení

51 V pasáži Tim. 29b5-c2 v prooimiu staví Timaios do kontrastu typ řečí, které jsou „ve všem všudy souladné a přesné“, a řeči, které jsou pravděpodobné, přičemž je zřejmé, že jeho vypravování bude náležet do druhé kategorie, nebot' se bude týkat vzniklého kosmu. V pasáži Tim. 48d1-4 se Timaios explicitně znovu odvolává na toto počáteční rozdělení, není ji tedy třeba dále komentovat. A konečně v pasáži Tim. 59c7-d2 je opět předveden již známý kontrast mezi bádáním o věčných jsoucnech a zkoumáním pravděpodobných vypravování o přírodě, jež lidem skýtá rozumnou a ušlechtilou zábavu.

52 Toto tvrzení je patrně založeno na následující úvaze: tak jako demiurg nemůže stvořit nic méně dokonalého, než jsou bohové, tak ani tito bohové nemohou stvořit nic méně dokonalého, než je člověk-muž. Ženy (a následně zvírata) tedy nemohou vzniknout dřív, než tito první mužští obyvatelé Země degenerují. K tomuto výčtu je třeba přiřadit ještě pasáž Tim. 68b6-8, v níž Timaios tvrdí, že i kdyby znal poměr, v jakém míšení vznikají určité barvy, nebyl by o tomto tématu schopen podat cixiòs $\lambda$ ó $\gamma$ os. 
plynoucí z lidské přirozenosti. V pasáži Tim. 29d2 se zdůrazňuje, že jelikož Timaios jakožto řečník i jeho posuzovatelé mají pouze lidskou povahu, sluší se, aby přijali pravděpodobný $\mu v \hat{\theta}$ os. V pasáži Tim. $68 \mathrm{~d} 2$ týkající se míšení barev jsou pak dle Johansena explicitně postaveny do kontrastu lidská a božská přirozenost co do své „znalosti a moci““ a o posledním výskytu Tim. 59c6, kde se pojednává o vzniku zlata a rudy, Johansen tvrdí, že i přes chybějící zmínku o lidské přirozenosti nemůže být pochyb o tom, že Timaios zde předpokládá lidský úhel pohledu..$^{53}$

Johansenovu tezi bychom mohli podpořit ještě jedním argumentem. Zdá se, že přinejmenším poslední dvě pasáže mají společný rys, jejž zbylé pasáže postrádají. V obou se jedná o problematiku míšení (jednou kovů, podruhé barev) a v obou případech se nacházíme v situaci, kdy byly právě vyloženy určité obecnější principy podpořené množstvím konkrétnějších příkladů, a jejich aplikace na možné další případy je považována za ne př́liš obtížnou. ${ }^{54}$ Avšak jakým způsobem jde dohromady toto konstatování snadnosti dalšího postupu s důrazem na omezení plynoucí z lidské přirozenosti, jež by mělo být základní charakteristikou mythické roviny? Povšimněme si, že zde navíc vstupuje do hry faktor experimentální ověřitelnosti, resp. neověritelnosti daných teorií. Zatímco na rovině $\log u$ se jednalo, jak jsme viděli, o otázky týkající se vzdálené minulosti, jejichž experimentální ověřitelnost vůbec nepřichází v úvahu, nyní se pohybujeme v oblasti míšení kovů či barev, tedy v oblasti, která by k experimentálnímu ověření mohla snadno svádět. V souladu s Johansenovou tezí bychom však mohli tvrdit, že toto ověření je nemožné díky omezení plynoucímu z lidské přirozenosti. $\mathrm{V}$ druhé zmíněné pasáži se totiž dozvídáme, že pokud by někdo při zkoumání těchto věcí chtěl užíti pokusu, dokázal by svou neznalost rozdílu mezi lidskou a božskou přirozeností (Tim. 68d2-4).

I přes veškeré naše počáteční sympatie $\mathrm{k}$ Johansenově snaze udržet také v rámci dialogu Timaios kontrast mezi mythem a logem se ve světle právě provedené analýzy relevantních pasáží zdá, že jeho výklad s sebou přináší více problémů, než kolik jich řeší. Johansen nachází společný jmenovatel pro pasáže Tim. 29d2 a 68d2 díky explicitnímu odkazu

53 T. K. Johansen, Plato's Natural Philosophy, str. 62-64.

54 Srv. inkriminované repliky: „O ostatních takových věcech není již nesnadno

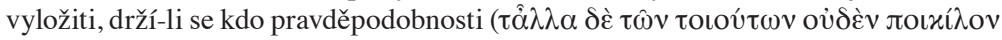

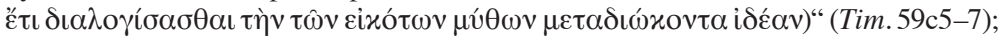
„Z těchto příkladů je snad patrno, jak lze podobným míšením pravděpodobně vylo-

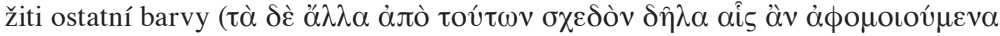

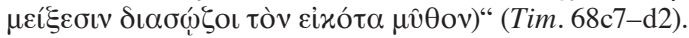


na lidskou přirozenost, avšak v druhém případě se spokojuje s nepř́iliš silným argumentem, že Timaios zde předpokládá lidský úhel pohledu. Náš argument týkající se experimentální ověřitelnosti zase poukazuje na souvislost pasáží Tim. 59c6 a 68d2, avšak pro Timaiovo uvození celé své řeči jako eixū̇s $\mu$ v̂ 0 s nenabízí žádné vysvětlení. Hlavním problémem, který v sobě Johansenův výklad implicitně obsahuje, je však to,

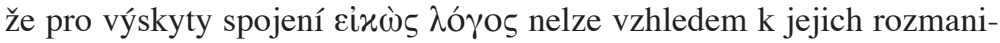
tosti najít žádného společného jmenovatele, jenž by zároveň neplatil pro

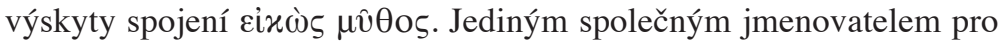
všech třináct výskytů se tedy zdá být onen důraz na termín eixós, tedy na to, že kvůli předmětu našeho zkoumání se stále pohybujeme na rovině pravděpodobnosti, avšak že i v rámci tohoto omezení činíme vše pro to, aby náš výklad byl rozumný a náležitý.

$\mathrm{Z}$ těchto důvodů jsme nuceni konstatovat, že Johansenův výklad nepřijímáme, nebot' se nám jej analýzou relevantních pasáží nepodařilo ani jednoznačně potvrdit, ani jednoznačně vyvrátit. Zdá se tedy, že pokud v rámci našeho dialogu existuje určitý rozdíl mezi spojeními cixòs $\lambda$ ófos a عixùs $\mu \hat{\theta} \theta 0 \varsigma$, je v každém případě velice subtilní a s největší pravděpodobností nemá určující filosofickou relevanci. ${ }^{55}$ Tím, co naopak zásadní filosofický význam má, je fakt, že se neustále pohybujeme na rovině pravděpodobnosti, což je určeno kombinací obou již zmíněných faktorů, tedy povahy předmětu našeho zkoumání a omezené moci plynoucí z naší lidské přirozenosti. ${ }^{56}$ Tento závěr potvrzují i četná

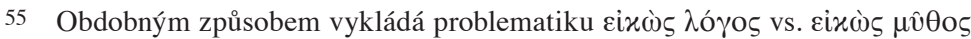
Thomas Robinson (viz T. M. Robinson, Plato's Psychology, str. xvii-xviii.), jenž dokonce píše, že oba termíny jsou v dialogu zcela zřejmě užívány synonymně (tamt., str. xvii, pozn. 6). Jistý pokus pro záchranu tohoto kontrastu činí ještě Myles Burnyeat, když píše: „It is not that $\mu \hat{\theta} \theta 0 \varsigma$ is equivalent to, and no different from

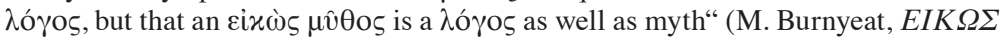
$M Y \Theta O \Sigma$, str. 145). Burnyeat chce tedy pravděpodobně tvrdit, že aby bylo možno $\mu v \hat{\theta}$ os na obecné úrovni kvalifikovat jako elxús, musí jeho dílčí součásti tvořit jak $\mu \hat{\theta} \theta$ os, tak $\lambda$ ó ${ }_{0} \varsigma$ či, jinými slovy, musí být onou výše zmíněnou kombinací

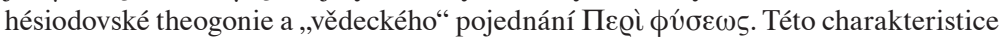
sice Timaiova řeč na první pohled odpovídá, je však zřejmé, že se Burnyeatův návrh odvíjí spíše od obecného předporozumění termínům $\mu$ $\theta$ os a $\lambda o ́ \gamma o \varsigma$, a nikoli od analýzy jejich výskytů v našem dialogu. Jelikož jsme však viděli, že způsob, jakým Timaios zachází s termíny $\mu$ v̂os a $\lambda o ́$ os, naprosto neodpovídá tomuto obecnému předporozumění, nemůžeme Burnyeatův návrh přijmout.

56 Srv. G. Betegh, What Makes a Myth eikós?, str. 219: „The upshot is that the difficulty we may face in formulating an account of a likeness depends not merely on the ontological status of the likeness, but also on our cognitive access to the maker, to his or her motivations and reasoning, and the process of the creation of 
užití odvozenin termínu cixús bez explicitní spojitosti at’ už s termínem $\lambda$ ó $\gamma$ os či $\mu \hat{v} \theta$ os.$^{57}$

Rovinu pravděpodobnosti se pak Johansen snaží přiblížit př́íkladem ze soudní síně, který snad má jisté opodstatnění díky Timaiovu označení

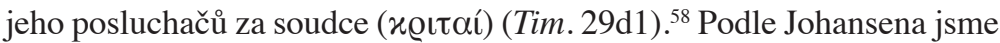
na tom podobně jako soudci, kteří nikdy nemohou mít naprostou jistotu např. o tom, kdo je pachatelem vraždy, i když mohou mít přesvědčivé důkazy vedoucí $k$ jedné osobě. Jejich verdikt bude vždy založený na přesvědčení ( $\pi i \sigma \tau ı \varsigma)$, které se díky oné kombinaci omezení plynoucí jednak z povahy předmětu zkoumání, jednak z naší lidské přirozenosti nikdy nemůže př̀tavit $\mathrm{v}$ naprosto jistou a nevývratnou pravdu $(\dot{\alpha} \lambda \hat{\eta} \theta \varepsilon \iota \alpha)$.

Tento př́ílad vhodným způsobem přibližuje restriktivní aspekt roviny pravděpodobnosti, avšak můžeme nalézt ještě jiný a závažnější důsledek. Nejde totiž pouze o to, že nemáme úplnou jistotu, zda se popisované děje staly přesně daným způsobem, ale zejména o to, že na ,přesné a ve všem všudy vnitřně souladné“ uchopení problematiky kosmogonie lidské myšlení, a tudíž ani lidská řeč (at' už ji nazveme $\mu v \hat{\theta o s}$ či $\lambda o ́ \gamma o \varsigma$ ) jednoduše nestačí. Pokud částečně předběhneme, můžeme říci, že Timaiova činnost je v jistém ohledu analogická činnosti demiurgově ${ }^{59}$ - oba musí nejdřive uchopit jistý vzor a uskutečnit jej v kvalitativně odlišném médiu (demiurg $\mathrm{v}$ chóře, Timaios $\mathrm{v}$ řeči), což má $\mathrm{v}$ obou případech za důsledek bytostně odlišný charakter, avšak zároveň bytostnou podobnost výsledného produktu a jeho vzoru. V př́ípadě demiurga se jedná o ideu ,živého tvora“ (viz Tim.30c2-31a1) a stvořený kosmos, v případě Timaia o reálně proběhnuvší kosmogonii a vyprávění o ní. Oba výtvory - kosmos a vyprávění o kosmogonii - jsou analogické v tom smyslu, že jsou podobné svému vzoru a zároveň od něj kvalitativně odlišné, což

the likeness.“ A obdobně tamt., str. 220: „,.. in so far as the relevant accounts need to include claims about the motivations and reasoning of the demiurgic god or gods, no human being is in a position to say anything certain about these matters." $\mathrm{Z}$ tohoto konstatování Betegh správně vyvozuje, že kdyby o stvoření kosmu chtěli poskytnout výklad bohové, pohyboval by se na rovině mnohem větší pravděpodobnosti než výklad lidský, avšak stále by byl eixús. Obdobně také W. K. C. Guthrie, A History of Greek Philosophy, V, The Later Plato and the Academy, Cambridge 1978, str. 252.

57 Viz např. Tim. 44d1, 48c1, 49b6, 56d1, 72d7, atd.

58 Viz T. K. Johansen, Plato's Natural Philosophy, str. 52.

59 Srv. taktéž již zmíněný začátek navazujícího dialogu Kritias, kde se Timaios modlí k bohu (tzn. ke kosmu), který skutkem vznikl již dávno, ale řečí právě ted' ( $\tau \hat{u}$

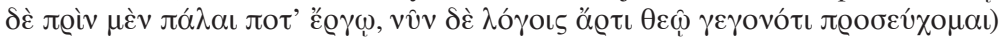
(Crit. 106a3-4). Obdobně jako demiurg před dávnými časy nechal vzniknout svět ve skutečnosti, Timaios nyní totéž učinil v řeči. 
lze shrnout do prostého konstatování: oba spadají do roviny pravděpo-

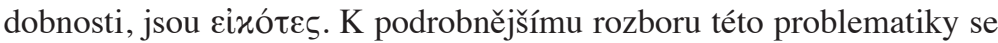
dostaneme v průběhu následujícího oddílu.

\section{Tvoření kosmu}

V předcházejících dvou oddílech jsme se zabývali otázkou, zda kosmos dle Timaia singulárně vznikl, či nikoli, a významem spojení cixòs $\mu \hat{\theta}$ os, jímž protagonista našeho dialogu uvozuje svoji „,velkou řeč“. V I. oddílu jsme argumentovali ve prospěch kladné odpovědi na první zmíněnou otázku, v II. oddílu jsme se snažili vyložit klíčový význam termínu عixús, který v sobě obsahuje určitý restriktivní aspekt, avšak zároveň představuje pozitivní standard, jemuž je třeba dostát. Tyto dva závěry musíme mít stále na paměti, nebot' pouze na jejich základě lze adekvátně porozumět následující Timaiově řeči týkající se toho, jak kosmos vznikl. Otázky „zda“ a ,jak“ jsou nepochybně úzce provázané, i přesto je však třeba mezi nimi rozlišovat a odpovědět na každou zvlášt' ${ }^{60}$ První otázka je v rámci prooimia (Tim. 27c5 a 28b6-7) explicitně formulována pouze dvakrát, poté se k ní Timaios již nevrací, ani jednoznačně netvrdí, že bychom ve světle nových skutečností měli odpověd’ na ni zásadním způsobem přehodnotit. Na rozdíl od některých badatelů, jejichž interpretace budou probírány níže, jsme proto přesvědčeni, že Timaios považuje svoji odpověd’ za uspokojivou a dostatečnou a nemá potřebu se k tomuto tématu znovu vracet ${ }^{61} \mathrm{~V}$ rámci tohoto oddílu se proto budeme soustředit

60 Tato teze není nijak samozřejmá, nebot', jak uvidíme níže na konkrétních př́íkladech, interpreti zpravidla volí jednu ze dvou strategií: bud’ se snaží doslovně vyložit všechny podstatné rysy Timaiova vyprávění a tvrdí, že kosmos vznikl přechodem z prekosmického stavu v sukcesivních fázích, anebo se naopak domnívají,že kosmos ve skutečnosti nejen nevznikal v sukcesivních fázích, ale že nelze hovořit ani o jeho singulárním vzniku z prekosmického stavu. Oba př́ístupy tedy implicitně předpokládají, že odpovědi na zmíněné otázky jsou na sobě vzájemně závislé, resp. že jedna determinuje druhou. Proti tomuto přesvědčení však oprávněně vystupuje například Sarah Broadiová, jež tvrdí, že reálná interpretace vzniku kosmu z prekosmu žádným způsobem nezavazuje k doslovné interpretaci jeho vznikání v sukcesivních fázích (S. Broadie, Nature and Divinity in Plato's Timaeus, str. 250). Tentýž názor, jak se zdá, zastává i Matthias Baltes, nebot' po vyvrácení teze, že kosmos vznikl v sukcesivních fázích, tvrdí, že by bylo ukvapené vyvodit pouze z této skutečnosti závěr, že

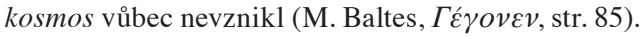

61 Tato skutečnost je zcela pochopitelná, nebot', jak se zdá, mezi Timaiovými společníky panuje v odpovědi na otázku, zda kosmos vznikl, shoda již od počátku, 
především na zodpovězení druhé zmíněné otázky, tedy otázky jak kosmos vznikl, resp. pokusíme se vysvětlit, jak rozumět Timaiovu popisu vznikání kosmu.

Začněme pasáží Tim. 47e5-48a5, z níž se dozvídáme, proč Timaiova řeč obsahuje dva kosmogonické výklady. ${ }^{62}$

„Počátek ( $\gamma \varepsilon \dot{v} \varepsilon \varepsilon \sigma \iota)$ tohoto světa totiž záležel ( $\dot{\varepsilon} \gamma \varepsilon v v \eta ́ \theta \eta)$ ve směsi z nutnosti a z tvůrčí činnosti rozumu; rozum však ovládal nutnost tím,

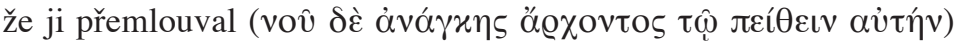
vésti většinu ze vznikajícího k nejvyšší dokonalosti: byl tedy na po-

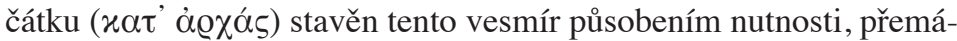
hané tímto způsobem a po této stránce od rozumné přemluvy." ${ }^{\text {"63 }}$

První výklad se zabývá onou „tvůrčí činností rozumu“, jež je vyobrazena jakožto činy demiurga (Tim. 29d7-47e2), druhý pak popisem vlivu nutnosti, již demiurg při své činnosti přemlouvá (Tim. 47e3-69a5). Základní charakteristikou demiurga je, že je dobrý a nemá závist ( $\phi \theta$ óvos) ${ }^{64}$ pročež chce, aby pokud možno také vše ostatní bylo co možná nejlepší. ${ }^{65}$ Proto vše uvádí $\mathrm{z}$ neuspořádaného stavu v řád, nebot' tento stav pokládá za lepší než onen (Tim. 29e1-30a6). Při této činnosti tvoří tělo i duši kosmu a vzorem mu je idea živého tvora - nejkrásnější ze jsoucen

tzn. ještě před zahájením samotné Timaiovy řeči - viz Kritiovu repliku, v níž ozna-

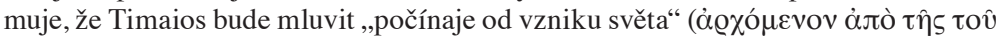

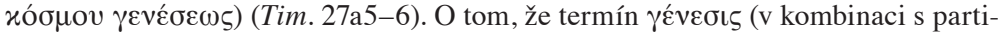
cipiem $\alpha \varrho \chi o ́ \mu \varepsilon v o v)$ v sobě zahrnuje, přinejmenším v této větě, představu počátku vznikání kosmu, nemůže být pochyb.

62 Dialog samozřejmě obsahuje ještě třetí výklad (Tim. 69a6-92c9), který oba předchozí výklady předpokládá a jehož hlavním tématem jsou smrtelné živé bytosti. Vzhledem k zaměření této studie se mu však nebudeme blíže věnovat.

63 Platón, Tim. 47e5-48a5.

64 Český termín „závist“ však není zcela adekvátním vystižením řeckého pojmu $\phi \theta$ óvos. Myles Burnyeat v této souvislosti správně podotýká, že obvyklé překlady ,,jealousy“ nebo „envy“ (stejně jako české „Závist“) vyžadují přítomnost druhé osoby, která v př́ípadě demiurga již z principu nemůže existovat. Z těchto důvodů vyzdvihuje Taylorův překlad, který $\phi \theta$ óvo s vystihuje jako sklon nechat si vše, co je dobré, pro sebe („disposition which seeks to engross all that is good for itself“, A. E. Taylor, A Commentary on Plato's Timaeus, str. 78) (M. Burnyeat, EIK $2 \Sigma M Y \Theta O \Sigma$, str. 159, pozn. 33).

65 Viz výklad Reginalda Hackfortha, jenž spojení ö

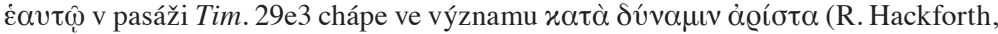
Plato's Theism, in: The Classical Quarterly, 1, 1936, str. 7, pozn. 1). 
nahlížených rozumem a ve všech ohledech dokonalá (Tim. 30d1-2) -, která v sobě objímá všechny pomyslné živé tvory. Těch jsou pak čtyři základní druhy: rod bohů na obloze, druh živočichů okřídlených a létajících vzduchem, druh žijící ve vodě a poslední chodící po nohách a žijící na suchu (Tim. 39e10-40a2). Jelikož demiurgova tvořitelská činnost se týká pouze bytostí nesmrtelných (viz Tim. 41b2-c3) (tzn. jednak kosmu, jednak astrálních bohů, kteří představují první ze čtyř druhů živých tvorů) ${ }^{66}$ přenechává dokončení kosmu (tedy vytvoření lidských bytostí) nižším bohům a sám následně dlí ve svém přirozeném stavu (č́ $\mu \varepsilon v \varepsilon v$ èv

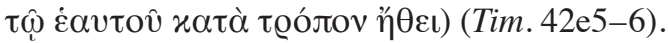

$\mathrm{V}$ druhém kosmogonickém vyprávění mapujícím vliv nutnosti přidává Timaios ke dvěma již dřive rozlišeným druhům (vzoru a jeho napo-

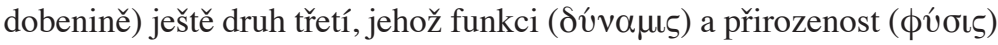
nejprve vysvětluje takto: ,jest to schrána všeho, co vzniklo, jakoby

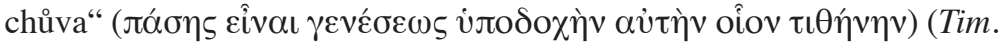
49a5-6). V souladu s tím tvrdí, že se jedná o cosi přirozeně tvárného

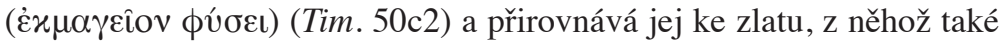
lze vytvářet rozličné tvary (Tim. 50a5-b5). V další části Timaiova výkladu (počínaje Tim. 51b6) se však ukazuje, že tento druh lze uchopit i odlišným způsobem. Podle tohoto textu se jedná spíše o prostor ( $\chi \omega ́ @ \alpha)$, jenž poskytuje místo všemu, co vzniká (Tim. 52a8-b5).

Zdá se tedy, že pokud se onen „třetí druh“ pokoušíme uchopit prostřednictvím řeči, můžeme rozlišit dva základní aspekty jeho přirozené povahy. Řečeno pozdější terminologií, „,řretí druh“ je jakousi ,pralátkou“, z níž demiurg vytváŕí smyslově vnímatelné tělo kosmu, avšak zároveň je prostorem poskytujícím místo všem vznikajícím věcem. ${ }^{67}$ Další klíčovou informací je, že „třetí druh“ existuje i před stvořením kosmu

66 Možná námitka by mohla znít, že demiurg také uspořádává čtyři živly, které nade vši pochybnost nejsou nesmrtelnými bytostmi. Avšak vzhledem k tomu, že uspořádání živlů není cílem samo o sobě, ale pouze prvním krokem při tvorbě těla kosmu, nelze tvrdit, že demiurg tvoří živly v témže smyslu, jako tvoří božské bytosti. Lépe je říci, že jedním z kroků při tvoření kosmu je uspořádání jednotlivých živlů, z nichž je následně sestaveno kosmické tělo. Viz zejména pasáž Tim. 53b1-5: „,... když v̌̌ak bi̊h se jal pořádati vesmír, tu nejprve určitě odlišil tvary a čísly...

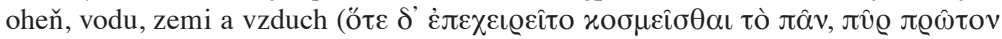

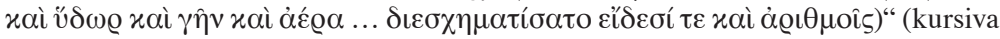
J. S.). K otázce, zda temporální následnost jednotlivých demiurgových činů chápat doslovně či metaforicky, se dostaneme v prủběhu následujícího výkladu.

67 Srv. D. Sedley, Hesiod's Theogony and Plato's Timaeus, str. 249. 
(viz Tim. 52d3-4), a tudíž je schránou/prostorem jak pro prekosmické vznikání, tak pro vznikání kosmické. ${ }^{6}$

Již výše jsme viděli, že badatele lze rozdělit do dvou protichůdných skupin, nebot' jedni se domnívají, že kosmos je singulárně vzniklý („,reálná interpretace“), zatímco druzí tvrdí, že je ve skutečnosti „pouze“ stále vznikající, nicméně nikdy nevzniklý (,metaforická interpretace“). Na tomto místě však je potřeba zvážit také další argumenty ve prospěch metaforické interpretace, které se opírají nikoli o text prooimia, ale o některé indicie, jež obsahuje Timaiova „,velká řeč““. ${ }^{69}$ Badatelé uvažující tímto způsobem volí v zásadě jednu ze dvou možných strategií: bud’ hledají další pozitivní argumenty pro svoji interpretaci, anebo poukazují na kontradikce, jež vyvstanou, budeme-li číst Timaiovu řeč doslovně. První strategii si přiblížíme na studii Gabriely Caroneové Creation in the „Timaeus“. The Middle Way. ${ }^{70}$

Autorka upozorňuje např́iklad na pasáž Tim. 38c2-3, kde je partici-

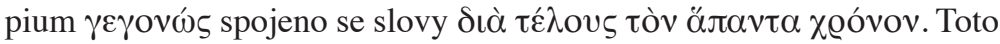

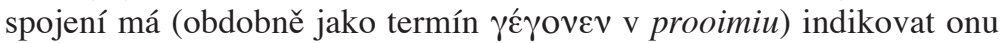
procesuálnost, jež nemá singulární počátek. Jiným autorčiným argumentem je odkaz na místa Tim. 37d6 a 37e3, kde jsou pro popis demiurgovy

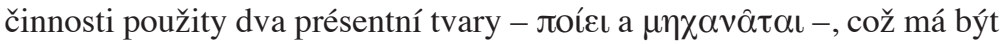
podle Caroneové znovu důkazem toho, že demiurg nestvořil svět v izolovaném okamžiku minulosti, ale tvoří jej ve skutečnosti stále. ${ }^{71}$

68 Je obtížnou otázkou, jaký je vztah mezi neuspořádaným prekosmickým vznikáním a jeho schránou/prostorem, v němž se odehrává, resp. zda vůbec lze mezi těmito dvěma aspekty prekosmického stavu smysluplně rozlišovat. Pro možnou odpověd’ na tuto otázku viz níže, pozn. 93.

69 Ze současných badatelů se $\mathrm{k}$ tomuto typu výkladu připojil např. i Charles Kahn ve své knize Plato and the Post-Socratic Dialogue, kde hájí standardní tezi metaforických interpretací, že analýza stavů před zásahem demiurga a po něm má za cíl rozlišení dvou typů kauzality - nutnosti a rozumu (C. H. Kahn, Plato and the Post-Socratic Dialogue. The Return to the Philosophy of Nature, Cambridge 2016, str. 189). Na jiném místě upozorňuje na obvyklý paradox stvoření kosmu v čase a stvoření času zároveň s kosmem, který však odbývá pouhým konstatováním, že se pravděpodobně jedná o jednu z nepřesností nutně plynoucích z formy Timaiova výkladu (viz Tim. 29c4-d3) (tamt., str. 178). Cílem Kahnova výkladu však není podrobný rozbor problematiky vzniku kosmu, a tak tato svá tvrzení nijak obsáhleji neodůvodňuje.

70 Je nutno podotknout, že sama autorka svoji interpretaci sice označuje, jak je patrno z názvu, za určitou „střední cestu“, avšak v jádru se jedná o klasickou metaforickou interpretaci, což bude zřejmé z následného představení jejích argumentů.

71 G. R. Carone, Creation in the „Timaeus“. The Middle Way, in: Apeiron, 3, 2004, str. 215-216. 


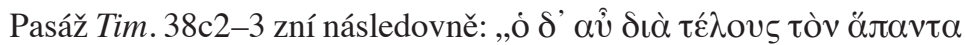

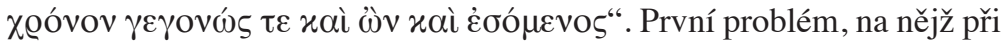
interpretaci tohoto textu narážíme, spočívá v tom, že gramaticky není zřejmé, k čemu odkazuje podmět uvedené věty (ó). Autorčin argument

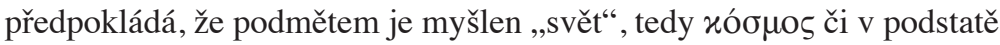
synonymní výraz oủoavós, avšak tak tomu nemusí být nutně. Inkriminovaná věta totiž následuje po známé pasáži o čase, a podmětem bezpro-

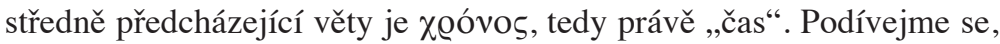
jak celá pasáž zní v Novotného překladu:

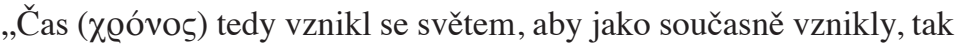
i současně zanikly, kdyby snad jednou došlo k jejich zániku, a vznik1 podle vzoru věčné přirozenosti, aby mu byl pokud možno nejpodobnější; nebot' vzor je po všechny věky jsoucí, kdežto čas (ó $\delta$ ' $\alpha \hat{\text { ) }}$ napořád v každé době minulý a jsoucí a budoucí." ${ }^{\text {"72 }}$

Autorčina volba číst jako podmět věty „svět“ má bezpochyby své opodstatnění, nebot' cílí na kontrast mezi paradeigmatem a jeho stvořenou kopií. Z jazykového hlediska však lze o její správnosti přinejmenším pochybovat, nebot' přirozenou volbou by mělo být dosazení podmětu

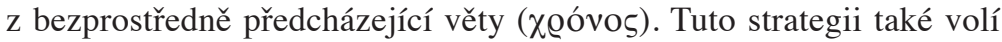
např. František Novotný nebo Luc Brisson ve svých překladech. ${ }^{73}$ Ter-

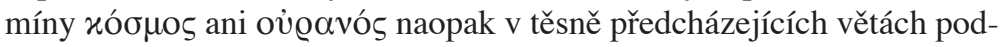
mětem nejsou, ov̉ @avós se nachází pouze $\mathrm{v}$ genitivu v právě citované pasáži, kde se praví, že čas vznikl se světem ( $\mu \varepsilon \tau$ ' oủo $\alpha v o v) .{ }^{74}$ Variantu

72 Platón, Tim. 38b6-c3.

73 S tímto čtením souhlasí rovněž Alfred Taylor, a to i přesto, že upozorňuje

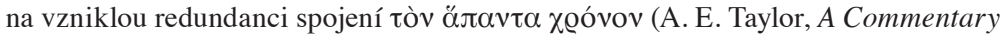

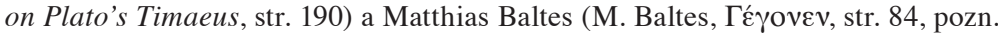
26, a str. 86-87, pozn. 33).

74 Možná námitka by mohla znít, že termín oủ @avós, byt' explicitně zmíněn pouze v uvedeném genitivu, ve skutečnosti figuruje jako podmět (i když nevyjád-

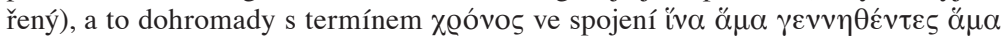

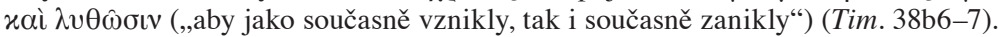
Tento postřeh je nepochybně správný, avšak opomíjí skutečnost, že inkriminovaná

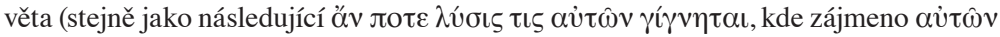
rovněž odkazuje k oběma termínům) je volně vložená, a není tak určující pro hlavní

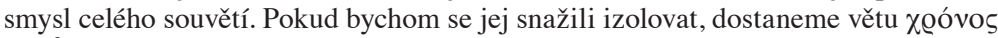

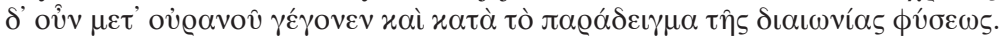
Základní sdělení se tedy nepochybně týká času, konkrétně toho, že vznikl spolu se světem a podle vzoru věčné prrirozenosti, a bylo by velmi zvláštní, kdyby Timaios 
čtení oủ @avós tedy, i přestože dává dobrý smysl, považujeme spíše za méně pravděpodobnou.

Pokud bychom však i navzdory těmto argumentům Caroneové čtení přijali, nejednalo by se o zásadní argument ve prospěch metaforické in-

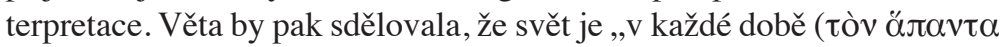

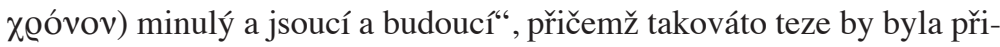
jatelná i v rámci naší interpretace. Popisoval by se tím stav světa $v$ čase, tedy v období, v němž je i o světě adekvátní tvrdit, že je neustále „,minulý a jsoucí a budoucí“. O prekosmickém stavu, tedy o stavu pred vznikem času, se zde nevypovídá nic, a tedy ani v této verzi není skutečnost singulárního vzniku světa/času žádným zpo̊sobem vyloučena.

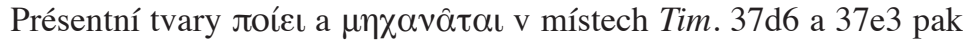
navrhujeme pochopit nikoli jako argument ve prospěch metaforické interpretace, ale jako tzv. historický présens, ${ }^{75}$ který Platón používá pro oživení vyprávění o minulých událostech. Čeština tento gramatický jev zná také, avšak na rozdíl od řečtiny používá za tímto účelem zpravidla čas budoucí. Tento návrh částečně potvrzuje opět František Novotný svým překladem, když alespoň první présens ( doucím časem, a jeho verze definice času zní tudíž následovně:

„... pojal úmysl učiniti jakýsi pohyblivý obraz věčnosti a pořádaje svět učiní ( $\pi$ oícı) podle věčnosti, trvající v jednotě, její věčný obraz s pohybem určovaným číslem, to, co jmenujeme čas. ${ }^{\text {"76 }}$

Za mnohem přínosnější považujeme strategii autorů upozorňujících na kontradikce či paradoxy vyvstanuvší při reálném (zde možná lépe „doslovném“) výkladu Timaiovy řeči. Tyto kontradikce pak, dle jejich názoru, mají čtenáře vést k odmítnutí reálné a přijetí metaforické interpretace. Za nejzávažnější paradoxy pokládáme tyto: 1) Timaios v pasáži Tim. 30a3 popisuje to, co se před zásahem demiurga nachází v neuspořádaném stavu (tzn. prekosmické vznikání), jako viditelné (ỏ@ $\alpha \tau o ́ v)$, což

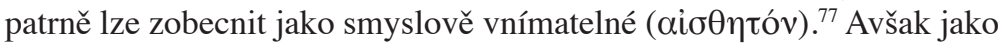

v následující větě bez jakékoli explicitní zmínky změnil téma a stavěl do kontrastu se vzorem nikoli čas, ale svět. To vše navíc pouze proto, aby se hned další větou explicitně vrátil zpět k problematice času: „Z takovéhoto rozumného úmyslu božího, aby vznik1 čas, byly stvořeny Slunce a Měsíc a pět jiných hvězd..." (Tim. $38 \mathrm{c} 3$ n.).

75 Viz H. W. Smyth, A Greek Grammar for Colleges, §1883.

76 Platón, Tim. 37d5-7 (kursiva J. S.).

77 Viz J. M. Dillon, The Riddle of the Timaeus. Is Plato Sowing Clues?, in: M. A. Joyal (vyd.), Studies in Plato and the Platonic Tradition, Aldershot 1997, 
takové by jednak muselo být vzniklé78 (Tim. 28b7-c2), jednak by muselo obsahovat (přinejmenším) prvek ohně ${ }^{79}$ (Tim. 31b5; srv. taktéž popis mechanismu zraku v Tim.45b6-46a2). Představa vzniku prekosmického stavu však působí zvláštně a v důsledku vede k nekonečnému regresu. Museli bychom totiž postulovat ještě jiný předcházející stav a tak dále $a d$ infinitum, jelikož demiurg není bůh tvořící ex nihilo ${ }^{80}$ Oheň pak v prekosmu zcela jistě obsažen být nemůže, protože stejně jako ostatní prvky je až výsledkem demiurgovy tvůrčí činnosti (Tim. 53b1-5). 2) Timaios popisuje pohyb, který se odehrává v prekosmickém stavu, a dokonce i některé jeho „zákonitosti“ (Tim. 52d4-53a7). V jakém smyslu však lze vůbec hovořit o pohybu, pokud čas (a to i ve smyslu lineární nezvratné následnosti - viz níže výklad pasáže Tim. 37e3-4 a pozn. 86 a 90) vzniká až spolu se světem ${ }^{81}$ (Tim. 38b6) a pokud by zdrojem veškerého pohybu měla být duše, která však v tuto chvíli ještě neexistuje? ${ }^{82}$ 3) Jak vůbec může Timaios za této situace smysluplně mluvit o době před vznikem světa ( $\gamma \varepsilon v \varepsilon ́ \sigma \theta \alpha \mathrm{l}-$ Tim. 53a7) $?^{83}$

str. 34, a L. Tarán, Creation Myth in Plato’s Timaeus, str. 323.

78 L. Tarán, Creation Myth in Plato's Timaeus, str. 323 a H. F. Cherniss, Aristotle's Criticism of Plato and the Academy, I, Baltimore 1944, str. 426, pozn. 361.

79 H. F. Cherniss, Aristotle's Criticism of Plato and the Academy, I, str. 426, pozn. 361 .

80 Srv. však úvahu Davida Sedleyho, který originálním způsobem srovnává timaiovskou kosmogonii s hésiodovskou theogonií a tvrdí, že prekosmický stav je analogií primordiálního chaosu, jenž bezpochyby, stejně jako každý komponent kosmu, vznikl. I přes tento fakt se jeho vznik však už žádným způsobem nevyloží. Sedley si uvědomuje, že toto srovnání sice nijak neřeší tenzi, která je v dialogu přítomna, ale relokuje problém do natolik vzdálené minulosti, že nepředstavuje reálné ohrožení pro Timaiův výklad, a navíc odpovídá počátečnímu varováním před nesouladností následující řeči v pasáži Tim. 29c4-d3. Autor závěrem trefně upozorňuje, že také v současné době jen mizivé procento explanačních teorií aspiruje na to (aniž by tím byl jakkoli ohrožen jejich status), aby došlo až k momentu Velkého třesku, a ještě méně ke stavu, který mu předcházel. Stejně tak Platón z pochopitelných důvodů rezignuje na vysvětlení toho, jaký mohl být počátek prekosmického chaosu (D. Sedley, Hesiod's Theogony and Plato's Timaeus, str. 251-252).

81 M. Baltes, Г'́ $\gamma$ ovev, str. 83-85.

82 Zde se výjimečně odvoláváme i na pasáže jiných Platónových dialogů, konkrétně Phaedr. 245c a Nom. 896b. Viz taktéž L. Tarán, Creation Myth in Plato's Timaeus, str. 325-331, a H. F. Cherniss, Aristotle's Criticism of Plato and the Academy, I, str. 426, pozn. 360.

83 Slavná formulace této námitky pochází od Alfreda Taylora: „No sane man could be meant to be understood literally in maintaining at once that time and the 
Skutečností mající nemalý význam je však to, že výše zmiňovaní autoři zpravidla koncipují své studie jako polemiku s tou verzí reálné interpretace, jejímž nejvýznamnějším představitelem je Gregory Vlastos. ${ }^{84}$ Podle jedné z Vlastosových základních tezí je třeba rozlišovat dva typy času. Ten, jejž stvořil demiurg současně se světem, je pohybem určovaným číslem a jeho existence je závislá na prrítomnosti periodických pohybů planet, jež jsou jeho měřítkem. Toto však prý nevylučuje možnost, že i před stvořením tohoto typu času existovala prostá nezvratná temporální následnost, tedy jakýsi „protočas“ ${ }^{85}$ Přinejmenším ve vysvětlení prekosmického pohybu, ve výrocích o době před vznikem kosmu a o jeho vzniku v čase tedy autor nespatřuje problém. Vlastosovu interpretaci však nepovažujeme za plausibilní. Nejen že text dialogu nijak nenasvědčuje tomu, že by Platón operoval se dvěma druhy času, dokonce se zdá, že tuto hypotézu vylučuje. V pasáži Tim. 37e4 totiž čteme, že

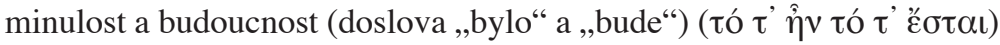

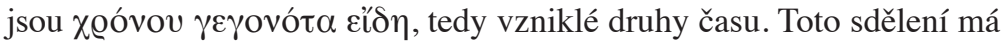
klíčový význam, nebot' dokládá, že vznik minulosti a budoucnosti, bez nichž není myslitelná ani Vlastosova prostá časová následnost, je jedním z rysů (dokonce bychom mohli tvrdit, že je základem) času stvořeného demiurgem, jejž nelze včítat do prekosmického stavu a jenž je jediným typem času, s nímž Timaios explicitně operuje. ${ }^{86}$

world began together, and also that there was a state of things, which he proceeds to describe, before there was any world“ (A. E. Taylor, A Commentary on Plato's

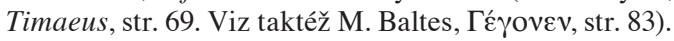

84 Explicitně L. Tarán, Creation Myth in Plato's Timaeus, str. 303. Užitečné a přehledné shrnutí argumentů ve prospěch metaforické interpretace a odpovědí na ně právě z vlastosovského pohledu nabízí Andrew Gregory. Viz A. Gregory, Ancient Greek Cosmogony, London 2007, str. 147-149.

85 G. Vlastos, Creation in the Timaeus, str. 272-274. Tento výklad, jak se zdá, implicitně přijímá také Elizabeth Jelinek (E. Jelinek, Pre-Cosmic Necessity in Plato's Timaeus, in: Apeiron, 3, 2011, str. 302) a otevřeně se k němu hlásí také Reginald Hackforth (R. Hackforth, Plato's Cosmogony (Timaeus 27dff.), in: The Classical Quarterly, 1, 1959, str. 22) či David Sedley (D. Sedley, Creationism and its Critics in Antiquity, str. 104-105). Je však třeba dodat, že tato myšlenka není zcela originálním přínosem zmíněných myslitelů 20. století, ale že se implicitně vyskytuje již u Cicerona a explicitně ji hájí přinejmenším dva střední platonici, konkrétně Plútarchos a Attikos. Viz R. Sorabji, Time, Creation \& the Continuum, str. 270.

86 K tomuto tématu viz také pozn. 90 . Vlastos se se zmíněnou pasáží vyrovnává následovně: Timaios podle něho sice tvrdí, že minulost a budoucnost vznikají společně s druhým typem času, ale nikde nedodává, že vznikají pouze s ním v jeho rámci, a proto není vyloučena jejich dřívější existence i v rámci prvního typu času (G. Vlastos, Creation in the Timaeus, str. 273-274). Vlastosovu interpretaci však 
Vidíme tedy, že jak interpretace metaforická, tak Vlastosovo doslovné čtení v sobě ukrývá několik zásadních a obtížně překonatelných problémů. Z tohoto důvodu se pokusíme ve zbývající části této studie navrhnout interpretaci vlastní, jež má ambici tyto problémy překonat. Na jedné straně se domníváme, že v odpovědi na otázku po singulárním vzniku kosmu je třeba jednoznačně upřednostnit reálnou interpretaci, nebot' její hlavní teze je pevně zakotvena již ve výše probíraném textu prooimia $\mathrm{k}$ Timaiově „,velké řeči“. Paradoxy a rozpory, které doslovné čtení Timaiovy řeči vyvolává, pak nemají, dle našeho názoru, za účel přivést čtenáře $\mathrm{k}$ radikálnímu přehodnocení hlavní teze prooimia. Jejich výskyt je totiž Timaiem předem avizován (Tim. 29c4-d3), a je snad dokonce nevyhnutelný kvůli kombinaci omezení plynoucích z ontologické povahy předmětu Timaiovy řeči (kosmu) a jeho lidské přirozenosti (viz výše podaný výklad termínu eixús). Na druhé straně však považujeme za plausibilní tezi metaforických interpretací, že existence těchto paradoxů má klíčový filosofický význam a že má poukázat na jisté meze „doslovné“ verze reálné interpretace. Tyto meze pak spočívají zejména v tom, že některé pasáže Timaiova výkladu se zdají být zřetelně kontradiktorní a že tyto kontradikce lze překonat pouze zavedením ad hoc hypotéz nemajících oporu v primárním textu (viz naši kritiku Vlastosova výkladu). Ze všech těchto důvodů jsme přesvědčeni, že adekvátní interpretace kosmogonické problematiky v dialogu Timaios nemůže být ani striktně doslovná, ani striktně metaforická, ale musí být kombinací obou těchto tradičních přístupů.$^{87}$

Náš dosavadní postup byl proto následující: vycházejíce z textu prooimia jsme se přiklonili k reálné interpretaci a tuto použili jako základ pro náš výklad. V jeho průběhu se však ukázalo, že pokud budeme v souladu s reálnou interpretací číst Timaiủv detailní popis vznikání kosmu doslovně, vyvstávají určité paradoxy a kontradikce, které patrně poukazují na obtížně překonatelné meze tohoto typu výkladu. Z této skutečnosti

v tomto ohledu považujeme za nepřesvědčivou, a proto ji nepřijímáme (obdobně

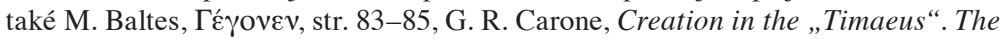
Middle Way, str. 217 a R. Sorabji, Time, Creation \& the Continuum, str. 274).

87 Naše interpretace by se dala zařadit do kategorie, kterou Andrew Gregory nazývá ,a qualified literal view“ (A. Gregory, Ancient Greek Cosmogony, str. 149). Tímto však nechceme říci, že náš pohled na timaiovskou kosmogonii je identický s tímto př́istupem. Gregory totiž reálnou interpretaci oslabuje ještě více a tvrdí, že Platónovým cílem snad ve skutečnosti nebylo podat popis konkrétní kosmogonie (soudě dle zmatenosti Timaiova výkladu), ale spíše načrtnout obecný kosmogonický princip týkající se přechodu z chaotičtějšího stavu ke kosmu (A. Gregory, Ancient Greek Cosmogony, str. 151). 
jsme následně usoudili, že je třeba alespoň částečně přijmout argumenty zastánců interpretace metaforické. Tento krok však (na rozdíl od naprosté většiny metaforických interpretů) nepovažujeme za důvod pro úplné opuštění interpretace reálné, ale pouze pro její zásadní modifikaci.

Pro lepší pochopení konkrétní podoby této modifikace se nyní ještě jednou vrat'me k onomu restriktivnímu rozměru termínu eixús plynoucímu z omezenosti naší lidské přirozenosti, který jsme výše již několikrát zmínili, ale podrobněji nevyložili. V moci lidského myšlení je vztahovat se jak k věčně jsoucímu, jež je neměnné, samo se sebou totožné a existující mimo čas i prostor, tak k proměnlivým časoprostorovým jevům náležejícím do sféry réveoıs. Kosmos je tělesný a smyslově vnímatelný a jako takový náleží mezi jsoucna druhého typu. I přsto je však v několika ohledech zcela výjimečný. Pro naše potřeby je zásadní zejména tato skutečnost: zatímco všechna ostatní jsoucna náležející do sféry $\gamma \varepsilon ́ v \varepsilon \sigma ı \varsigma$ vznikají $v$ čase, kosmos vzniká spolu s časem, resp., lépe řečeno, čas vzniká spolu s kosmem (Tim. 38b6). Domníváme se proto, že přechod $\mathrm{z}$ prekosmu ke kosmu je nutně singulární událostî ${ }^{88}$ a lidské myšlení či lidská řeč tak z pochopitelných důvodů naráží př̀i pokusu o jeho uchopení na své meze. $\mathrm{V}$ porovnání $\mathrm{s}$ věčně jsoucím totiž v samém jádru kosmogonie figuruje určitá změna, avšak v porovnání se jsoucny ze sféry

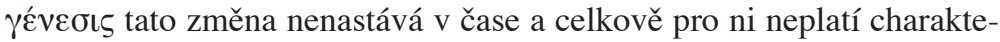
ristiky vlastní jakýmkoli změnám v rámci kosmu. Z tohoto důvodu jsme přesvědčeni, že prapůvodní kosmogonickou událost nelze lidským myšlením pojmout zcela adekvátním způsobem a že se její pravé podstatě můžeme různými prostředky pouze více či méně přibližovat (v Timaiově konkrétním př́ípadě se toto děje prostř̌ednictvím jeho, ,pravděpodobného vyprávění“).

Timaios s největší pravděpodobností vychází primárně ze skutečnosti,

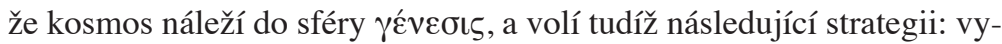
práví o změně prekosmu v kosmos jako by se bývala odehrála v čase, tzn. prezentuje ji jako řadu sukcesivních fází, a tímto způsobem se pokouší zprostř̌edkovat své mínění o jejím charakteru, jejích př́ǐinách a důsledcích ostatním lidským bytostem. Domníváme se proto, že tento temporální aspekt Timaiova výkladu neodráží povahu skutečně proběhnuvší kosmogonie a nemá být interpretován doslovně. Sám Timaios ve prospěch tohoto tvrzení navíc poskytuje jednu poměrně explicitní indicii:

88 Čistě hypoteticky by sice čas i kosmos mohly zaniknout, a poté opět být stvořeny, avšak k jejich zániku (stejně jako k zániku dalších božských bytostí) ve skutečnosti nikdy nedojde, protože tento čin by odporoval demiurgově dobrotě (viz Tim. 30a6-7, 41a7- b6). 
uspořádáním své řeči vyvolá u čtenáře dojem, že demiurg nejprve vytváří tělo kosmu a teprve poté jeho duši (Tim. 31b4-34b9), avšak pouze proto, aby vzápětí celou věc ,uvedl na pravou míru“ a označil duši

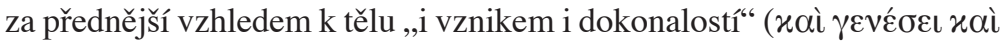

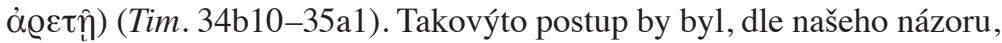
velice matoucí, pokud by jím Platón nechtěl záměrně upozornit na nutnost nedoslovného výkladu temporálního aspektu Timaiova kosmogonického vyprávění.

Pokusme se vzhledem k právě řečenému lépe objasnit onu výše zmíněnou analogii mezi demiurgovou a Timaiovou činností. Oba tvoří podobnou kopii určitého vzoru v kvalitativně odlišném médiu: zatímco demiurg tvoří viditelný a hmatatelný kosmos podle věčné ideje živého tvora, Timaios vypráví o kosmogonii podle reálně proběhnuvší kosmogonie.$^{89}$ Oba musí úvahou nalézt, co pro kopii v rámci kvalitativně odlišného média znamená být podobný svému vzoru, nebot' stejně jako demiurg nemůže stvořenému kosmu poskytnout charakter věčně jsoucího, ani Timaios nemůže $\mathrm{v}$ rámci svého vyprávění zcela adekvátně zachytit pravou povahu prekosmického stavu a kosmogonického aktu. Oba stojí před podobným problémem, a oba tak volí do jisté míry podobnou strategii k jeho vyřešení - dopomáhají si zavedením času. ${ }^{90}$ Demiurg dopřává

89 Určitá nepřesnost této analogie samozřejmě nutně plyne ze srovnání kognitivních schopností demiurga a Timaia. Zatímco demiurg pravděpodobně disponuje dokonalým poznáním svého vzoru, o vztahu Timaia a reálné kosmogonie toto jistě říci nelze. Dodejme tedy, že Timaiův výklad se pohybuje na rovině pravděpodobnosti nejen z toho důvodu, že (po vzoru demiurga) provádí převod mezi dvěma odlišnými typy skutečnosti, ale také proto, že plné poznání reálné kosmogonie je z lidské perspektivy nedostupné, a tak v podstatě neexistuje záruka faktické přesnosti jeho vyprávění.

90 Není cílem této studie podrobně se zabývat složitou problematikou času v Timaiovi, avšak je třeba zmínit alespoň několik zásadních bodů. V první řadě se domníváme, že na rozdíl od mnoha pozdějších myslitelů Timaios pracuje s časem jakožto objektivním rysem stvořeného kosmu, umocňujícím jeho podobnost ideálnímu vzoru, a že jej bytostně spojuje s existencí pohybu fyzikálních těles, jehož primární charakteristikou je právě ona nezvratná temporální následnost, a nikoli pravidelnost. To vyplývá z již zmiňované pasáže Tim. 37e3-5, kde je ono „bylo“a „bude“ označeno za vzniklé druhy času, a rovněž z bezprostředně následující pasáže Tim. 38a1-2,

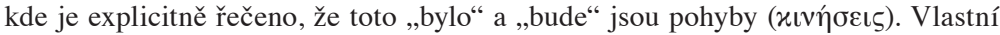
jádro času (spočívající v existenci rozdílu mezi minulostí a budoucností) a vlastní jádro pohybu (spočívající v nezvratné následnosti jeho jednotlivých fází) jsou tedy ve skutečnosti dvěma aspekty téhož fenoménu, kterým demiurg zvyšuje podobnost kosmu ideálnímu vzoru. Neméně důležitým, avšak až sekundárním faktem je, že díky pravidelnosti pohybu nebeských těles je možné, aby byl čas měřen duší (at' už lidskou či světovou). Není pravděpodobně sporu o tom, že čas je v Timaiovi 
kosmu věčné trvání v čase, čímž zvyšuje jeho podobnost neměnné věčnosti vzoru, Timaios zase kosmogonickou událost prezentuje jako temporální sukcesi jednotlivých fází, což mu umožňuje lépe vyložit své mínění o ní. Pokud je tato interpretace plausibilní, znamená to, jak jsme již naznačili výše, že ani do prekosmického stavu, ani do demiurgovy činnosti vedoucí k ustavení kosmu nelze včítat časovost, a to dokonce ani ve smyslu nezvratné temporální sukcese (viz Tim. 37e4).

Na samotný závěr alespoň stručně načrtněme způsob, jakým by naše interpretace mohla řešit zmíněné paradoxy inherentní Timaiově řeči. První paradox se týká skutečnosti, že také v prekosmickém stavu se dle

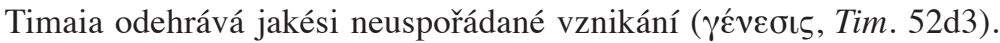
Tuto $\gamma \varepsilon ́ v \varepsilon \sigma ı \varsigma$ navrhujeme chápat nikoli jako vznikání v pravém smyslu slova se všemi jeho zákonitostmi, které platí v rámci kosmu, ${ }^{11}$ ale spíše

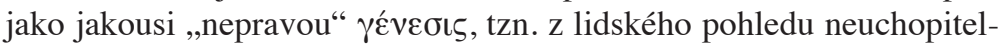

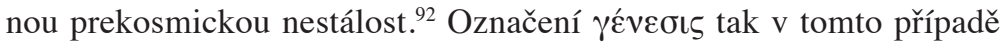

měřitelný pouze duší a že toto měření (v případě světové duše) skutečně probíhá od samého počátku existence světa. I přesto ale platí, že jeho samotná existence je primárně spjatá s oním pohybem fyzikálních těles, a tudíž je na jakékoli duši ve své podstatě nezávislá. Pro opačnou interpretaci času jakožto fenoménu bytostně existujícího pouze v duši viz např. E. Brann, Time in the Timaeus, in: týž, The Music of the Republic. Essays on Socrates' Conversations and Plato's Writings, Philadelphia 2011, str. 276-277.

91 Obtížnou otázkou je, zda prekosmické vznikání disponuje svými vlastními „zákony“, anebo zda je jakýchkoli zákonů prosté. V souladu s naší interpretací bychom se přiklonili spíše ke druhé možnosti, avšak jsme si vědomi toho, že toto řešení není neproblematické, a to zejména v konfrontaci s pasáží Tim. 52d4-53b5, která nasvědčuje existenci prekosmických principů heterogenity sil působících pohyb a shlukování podobného. Na základě naší interpretace bychom mohli tvrdit, že první z těchto ,principů pohybu“ má nejspíše vystihovat onu inherentní nestálost prekosmického vznikání, zatímco druhý Timaios připisuje prekosmu pravděpodobně na základě silného vlivu tradice - viz komentár̆ Francise Cornforda, jenž upozorňuje, že princip shlukování podobného byl v Platónově době v podstatě axiómem přežívajícím již z filosofie atomismu a ztělesňujícím jakousi spontánní hybnou sílu vlastní samotné přírodě (F. M. Cornford, Plato's Cosmology, str. 168-169).

92 Tuto neuchopitelnost a bytostnou odlišnost prekosmického ,pohybu“ zcela pregnantně vystihuje Thomas M. Robinson, Plato's Psychology, str. 97: „The Phaedrus seems to be saying that soul is the cause of all movement in an organised world, a world measurable by time. In a non-organised world not measurable by time it is debatable whether the movement in question has anything to do with this. Plato is compelled to give some description of the pre-cosmic chaos, and talk of movement in such a world is no more and no less intelligible than phrases like ,before this“ (л@ó

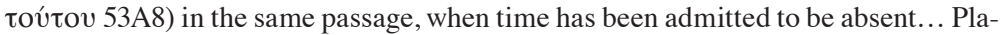
to, as far as I can see, is dealing in two instances with two completely different types 
považujeme za pouhou metaforu pro tuto neuchopitelnou nestálost, jež je svojí povahou zcela protikladná vůči stálosti a neměnnosti věčně jsoucího vzoru.$^{93}$ Stejně tak označení prekosmického „,vznikání“ adjektivem

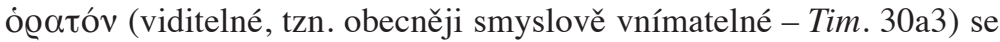
zdá být metaforickým (nebot' bez přítomnosti ohně nemůže být nic viditelné - Tim. 31b5) a za jeho účel opět považujeme vyzdvižení bytostné odlišnosti mezi nestálostí prekosmu a věčně jsoucím vzorem, mezi jehož základní charakteristiky patří mimo jiné nepřístupnost smyslovému vnímání. V neposlední řadě pak připomeňme Timaiovy zmínky o tom, co bylo před vznikem světa, které, pokud čas vzniká spolu se světem, rovněž nemohou být vykládány doslovně. Jelikož za této situace tedy nelze striktně vzato hovořit o stavu před vznikem světa, domníváme se, že Timaios chce touto formulací vyjádřit své přesvědčení, že prekosmos jako takový není pouhou metaforou či kontrafaktuálním popisem našeho světa, nýbrž stavem, v němž se veškerenstvo skutečně nacházelo a z něhož bylo demiurgem transformováno ve stav kosmický. ${ }^{94}$

\section{ZUSAMMENFASSUNG}

Ziel der Studie ist die Beleuchtung von einigen der zentralen Fragestellungen in Platons Timaois. Nach einer kurzen Einführung wird die Frage diskutiert, ob Kosmos - nach Timaios - einst entstand oder wenn nicht, ob er immer noch im Begriff ist zu entstehen. Um diese Frage zu

of motion, the one accepted and universally admitted, and operating in an organised world of temporal succession, the other a reality in every sense different, and almost beyond description."

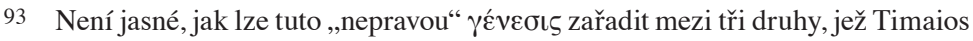
rozlišuje na počátku svého druhého kosmogonického vypravování: 1) to, co vzniká

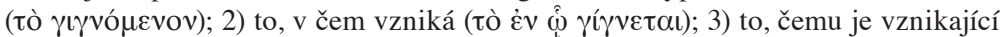

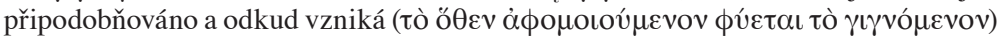
(Tim. 50c7-d2). Rozhodně ji nelze ztotožnit ani s tím, co vzniká, nebot' to musí nutně odkazovat až ke stvořenému kosmu, a bezpochyby ani s ideálním vzorem, kterému je vznikající připodobňováno. Domníváme se tedy, že onen neuspořádaný ,pohyb“ protoživlů bude v prekosmu s největší pravděpodobností neodlišitelný, resp. odlišitelný pouze pojmově, od „matky“, tzn. od toho, ,, čem vzniká“, a že teprve až činností

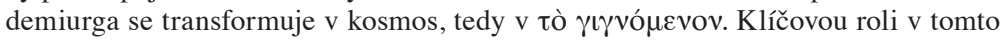
argumentu hraje fakt, že ,třetí druh“ nelze pochopit (řěeno pozdější terminologií) ani jako prostor, ani jako ,pralátku“, ale jako kombinaci obojího. Srv. D. Sedley, Hesiod's Theogony and Plato's Timaeus, str. 249.

94 Tato studie vznikla v rámci projektu č. 341715 Kosmos jako živá bytost $v$ antické filosofii a byla financována z prostředků Grantové agentury UK. 
beantworten, wird eine sorgfältige Analyse des Proömiums der Timaios' Rede (Tim. 27c1-29d3) vorgelegt und die Differenz zwischen der sog. realen und metaphorischen Interpretation dargestellt und entfaltet. Die

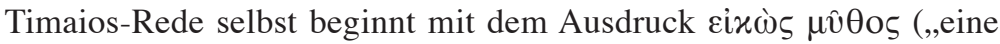
wahrscheinliche Rede“ - Tim. 29d2), der die Rede wesentlich bestimmt. Das folgende Kapitel ist deshalb einer Interpretation gewidmet, die den Sinn dieses Ausdrucks untersucht und zugleich allgemein dem Thema, wie man über Kosmos eine Rede halten kann. Den letzten und längsten Teil des Textes bilden die Ergebnisse der vorherigen Untersuchungen und Präsentierung der Antworten auf die Frage, wie das Entstehen des Kosmos genau verstanden werden soll. Dabei werden Thesen von einigen renommierten Wissenschaftlern kritisch ausgewertet. Im letzten Abschnitt wird eine Interpretation vorgestellt, die die beiden traditionellen Lösungsansätze auf originelle Art und Weise zu kombinieren versucht.

SUMMARY

The aim of this paper is to clarify some of the key problems of Plato's Timaeus. After the short introduction the question whether the cosmos, according to Timaeus, once came into being or whether it never did but is still coming into being is being discussed. In order to answer this question a careful analysis of the prooemium to the Timaeus' speech (Tim. $27 \mathrm{c} 1-29 \mathrm{~d} 3$ ) is made and a distinction between so-called real and metaphorical interpretation is developed. Timaeus' speech itself is introduced

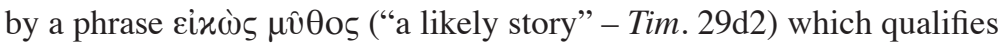
it essentially, and the following section is, therefore, dedicated to an interpretation of the meaning of this phrase and generally to the topic of speech which can be delivered about cosmos. The last and longest part of the text builds on the results of preceding enquiry and answers the question how exactly should be the coming into being of cosmos understood. Theses of several renowned researchers are critically assessed and in the last section an interpretation which tries to combine both traditional approaches in an original way is presented. 